\title{
Hydrothermal Cobalt Doping of Titanium Dioxide Nanotubes towards Photoanode Activity Enhancement
}

\author{
Mariusz Wtulich ${ }^{1}{ }^{\circledR}$, Mariusz Szkoda ${ }^{1}$, Grzegorz Gajowiec ${ }^{2}$, Maria Gazda ${ }^{3}{ }^{\circledR}$, Kacper Jurak ${ }^{4}$, \\ Mirosław Sawczak ${ }^{5}$ (D) and Anna Lisowska-Oleksiak ${ }^{1, *(D)}$ \\ 1 Department of Chemistry and Technology of Functional Materials, Chemical Faculty, Gdańsk University of \\ Technology, 80-233 Gdańsk, Poland; wturglish@gmail.com (M.W.); mariusz.szkoda1@pg.edu.pl (M.S.) \\ 2 Faculty of Mechanical Engineering and Ship Technology, Institute of Machine Technology and Materials, \\ Gdansk University of Technology, 80-233 Gdansk, Poland; grzgajow@pg.edu.pl \\ 3 Department of Solid State Physics, Faculty of Applied Physics and Mathematics, Gdansk University of \\ Technology, 80-233 Gdansk, Poland; maria.gazda@pg.edu.pl \\ 4 Department of Electrochemistry, Corrosion and Materials Engineering, Chemical Faculty, Gdansk University \\ of Technology, 80-233 Gdańsk, Poland; kacper.jurak@pg.edu.pl \\ 5 The Szewalski Institute of Fluid-Flow Machinery, Polish Academy of Sciences, 80-231 Gdańsk, Poland; \\ mireks@imp.gda.pl \\ * Correspondence: alo@pg.edu.pl
}

Citation: Wtulich, M.; Szkoda, M.; Gajowiec, G.; Gazda, M.; Jurak, K.; Sawczak, M.; Lisowska-Oleksiak, A. Hydrothermal Cobalt Doping of Titanium Dioxide Nanotubes towards Photoanode Activity Enhancement. Materials 2021, 14, 1507.

https://doi.org/10.3390/ma14061507

Academic Editor: Rosalinda Inguanta

Received: 18 February 2021

Accepted: 15 March 2021

Published: 19 March 2021

Publisher's Note: MDPI stays neutral with regard to jurisdictional claims in published maps and institutional affiliations.

Copyright: (c) 2021 by the authors. Licensee MDPI, Basel, Switzerland. This article is an open access article distributed under the terms and conditions of the Creative Commons Attribution (CC BY) license (https:/ / creativecommons.org/licenses/by/ $4.0 /)$.

\begin{abstract}
Doping and modification of $\mathrm{TiO}_{2}$ nanotubes were carried out using the hydrothermal method. The introduction of small amounts of cobalt (0.1 at \%) into the structure of anatase caused an increase in the absorption of light in the visible spectrum, changes in the position of the flat band potential, a decrease in the threshold potential of water oxidation in the dark, and a significant increase in the anode photocurrent. The material was characterized by the SEM, EDX, and XRD methods, Raman spectroscopy, XPS, and UV-Vis reflectance measurements. Electrochemical measurement was used along with a number of electrochemical methods: chronoamperometry, electrochemical impedance spectroscopy, cyclic voltammetry, and linear sweep voltammetry in dark conditions and under solar light illumination. Improved photoelectrocatalytic activity of cobalt-doped $\mathrm{TiO}_{2}$ nanotubes is achieved mainly due to its regular nanostructure and real surface area increase, as well as improved visible light absorption for an appropriate dopant concentration.
\end{abstract}

Keywords: titanium dioxide; hydrothermal modification; photoanode; water splitting; Co-doping

\section{Introduction}

The greatest challenge for the 21st century is without doubt combatting climate change. Globally, we should reduce fossil-originated energy consumption [1]. In response to the requests of society, it is now vital that new, environmentally friendly energy conversion and storage equipment is available; consequently, there has been a colossal development of research in this topic. The performance of energy conversion and storage electrochemical devices depends on the materials they are made of. The innovative solution in material chemistry is very often based on nanotechnology. Nanostructured materials hold the key to the novel generation of supercapacitors, lithium-ion/sodium-ion batteries, thermoelectric cells, and photoelectrochemical cells (PEC) [2-7]. Considering the PEC cell, the heart of the light energy harvesting module is the photoanode [5]. The history of photoanode material development starts half a century ago with the discovery of the photoelectroactivity of the $\mathrm{TiO}_{2}$ monocrystal electrode under UV electromagnetic wave illumination [8]. Great effort has been undertaken globally to give us novel semiconductor materials with a narrow bandgap, such as $\mathrm{BiVO}_{4}, \mathrm{Fe}_{3} \mathrm{O}_{4}, \mathrm{WO}_{3}$, and their derivatives [9-12], allowing visible light absorption [7-12]. The strategy to increase the photoactivity and electroactivity of $\mathrm{TiO}_{2}$ focuses on modifying the position of the electron bands of the material by doping with non-metals $[13,14]$, by metal doping $[6,7,15]$, or the application of surface sensitizers [16]. 
The importance of morphology was demonstrated by studies of $\mathrm{TiO}_{2}$ nanostructures. Early reports on the possibility of growing titanium dioxide nanotubes come from AssefpourDezfuly et al., who managed to obtain them from an acidic electrolyte containing fluoride ions and chromic acid brushes a few hundred nanometers thick [17].

Kasuga et al. produced chemically titania nanotubes (TiNTs) of a diameter below $10 \mathrm{~nm}$ [18]. Other chemically synthesized nanotubes are mainly tested in lithium batteries [19]. The earliest fully successful attempt of electrochemical synthesis came from Zwilling et al. in 1999, who reported the first self-organized nanotube coating on a Ti substrate obtained by electrochemical Ti anodization in chromic acid electrolytes containing fluoride ions [20]. Since that point, the interest in the method has increased enormously and the technology of producing nanotubes has developed extensively.

Electrochemical methods were improved significantly in the so-called second generation of titania nanotubes, produced in neutral electrolytes [21]. The most popular method nowadays is growing them from viscous mixed solvent electrolytes based on ethylene glycol (EG), with a complexing agent $\mathrm{F}^{-}$in the form of $\mathrm{HF}$ and $\mathrm{NH}_{4} \mathrm{~F}$, often with $\mathrm{H}_{3} \mathrm{PO}_{4}$ [22-24]. Application of TiNTs grown on the Ti support includes their use in PEC cells, encapsulation of drugs, air purification, water purification, construction of sensors, and use in electrochemical capacitors [25-29]. TiNTs in photoelectrochemical devices act as UV-Vis light absorbing photoanode material. Although the size of the bandgap of nanotubes is reduced compared to pure bulk anatase $\mathrm{TiO}_{2}(3.2 \mathrm{eV})$, a lot of effort has still been exerted by researchers to obtain higher parameters of photoactivity. The absorption edge of measured spectra for $\mathrm{TiO}_{2}$ nanotube on Ti substrate is shifted slightly towards the visible range compared to pure bulk anatase $\mathrm{TiO}_{2}$ powder. This is due to the fact that the barrier layer present at the $\mathrm{TiO}_{2}$ nanotube- $-\mathrm{Ti}$ substrate interface has rutile crystallites, and the nanotube walls consist of anatase crystallites. The bandgap of the rutile is lower compared to the anatase. The rutile phase at the barrier layer leads to the shifting of the absorption edge to a higher wavelength $[30,31]$. The presence of $\mathrm{Ti}^{3+}$ in the tubular structure of $\mathrm{TiO}_{2}$ is also important for the absorption of light. After anodizing, the layers are subjected to a thermal process which causes the formation of oxygen vacancies and reduction of Ti(IV) to Ti(III). This surface-reduced material shows red shift absorption and better electrical conductivity [32]. There are several ways, as with ordinary structures, to increase the photoelectroactivity of nanotubes. Here, we have doping with non-metals [33,34], metal doping [35], and the use of systems with a co-catalyst as reported for $\mathrm{Fe}_{3} \mathrm{O}_{4}$ and $\mathrm{CoO}_{x}$ decorated titania nanotubes towards water splitting [36,37].

In this study, we focus on transition metal, namely $\mathrm{Co}$, doping of the $\mathrm{TiO}_{2}$ nanotube structure towards water photoanodic oxidation. Previous reports on photocatalytic organic pollutants degradation show that doping the anatase powder with cobalt leads to the enhancement of photoactivity in the process of phenol disposal from water or dye decoloration [38-40]. Very small amounts of cobalt (0.1-3 at \%) introduced into the structure contribute to a significant increase in the photocatalytic organic pollutant decomposition efficiency [38].

Since the photocatalytic activity of Co-doped $\mathrm{TiO}_{2}$ is documented, one may expect that the material could be in PEC cells as a photoanode. Titania nanotubes, the synthesis of which is easily controlled, were chosen as starting materials. The Co-doping of the $\mathrm{TiO}_{2}$ structure is performed using a hydrothermal procedure.

The goal of this work is to demonstrate the influence of the hydrothermal process, leading to a slight introduction of cobalt ions into the nanotubes, in the photoanode process of water oxidation. The novel electrode material is characterized using $\mathrm{X}$-ray powder diffraction (XRD) analysis, Raman spectroscopy, UV-Vis spectroscopy, X-ray photoelectron spectrometry (XPS), scanning electron microscopy (SEM), electrochemical methods: electrochemical impedance spectroscopy (EIS), cyclic voltammetry (CV), linear sweep voltammetry (LSV), and chronoamperometry (CA) in the dark and under solar light illumination. We demonstrated that a small amount of Co $(\sim 0.1$ at \%) inserted hydrothermally into the $\mathrm{TiO}_{2}$ nanotubes causes a threefold increase in the photocurrent under solar light 
illumination. The hydrothermal method turned out to be a very effective and cheap way to obtain a material with high photoactivity.

\section{Materials and Methods}

\subsection{Apparatus}

The microscopic studies were performed using JSM-7800 F (JEOL, Tokyo, Japan) field emission scanning electron microscope on the surface of pure $\mathrm{TiO}_{2}$ and with cobalt dopant. The images were analyzed using a beam accelerating voltage at $5 \mathrm{kV}$. EDX analysis was used for chemical elements detection by a silicon nitride window's detector (OCTANE ELITE model, EDAX company, Mahwah, NJ, USA).

The crystal structure was determined from the XRD pattern using a diffractometer (Xpert PRO-MPD, Philips, Amsterdam, The Netherlands) with $\mathrm{CuK} \alpha$ emission $(\lambda=1.5406 \AA)$. The crystallites sizes were estimated based on the Scherrer formula and were processed using Fityk software [41] via fitting to the Gaussian function. UV-Vis spectra were recorded in the from $200 \mathrm{~nm}$ to $800 \mathrm{~nm}$ by a Perkin Elmer UV-Vis spectrometer (Lambda 35, Perkin Elmer, Waltham, MA, USA) equipped with the integrating sphere module for reflectance measurements. The Raman analysis was performed using a Raman microscope (InVia, Renishaw, Wotton-under-Edge, UK). Spectra were received using an argon-ion laser emitting at $514 \mathrm{~nm}$. The spectrum of every single point at the sample was recorded as an accumulation of three scans.

XPS measurements of the electrode materials were performed on the Escalab 250Xi device (Thermo Fisher Scientific, Waltham, MA, USA). Al K $\alpha$ radiation was used. The spectra of elements were analyzed and deconvoluted into components described by an envelope of a Gaussian-Lorentzian sum function with an asymmetry tail supported by the spectrometer commercial software Avantage version 5.973 [42]. The binding energies obtained in the XPS analysis are given relative to the C1s line at $284.6 \mathrm{eV}$. Traces amounts of cobalt were searched for, therefore the largest possible spot width with a diameter of $650 \mu \mathrm{m}$ was used.

The electrochemical examinations in the dark of $\mathrm{TiO}_{2}-\mathrm{NTs}, \mathrm{Co}-\mathrm{TiO}_{2}-\mathrm{NTs}$ and $\mathrm{Co}-\mathrm{TiO}_{2}$ samples were carried out with a potentiostat-galvanostat (AutolabPGStat10 with an FRA module, Eco Chemie B.V, Utrecht, The Netherland and Autolab PGSTAT 30, Metrohm Autolab B.V., Utrecht, The Netherlands) in a three-electrode glassy cell with titanium modified foils as the working electrode, $\mathrm{Ag} / \mathrm{AgCl} / 0.1 \mathrm{M} \mathrm{KCl}$ as the reference electrode, and platinum mesh as the auxiliary electrode. Cyclic voltammetry, linear sweep voltammetry, chronoamperometry and electrochemical impedance spectroscopy were conducted in $0.1 \mathrm{M}$ $\mathrm{K}_{2} \mathrm{SO}_{4}$, purged with argon gas for $30 \mathrm{~min}$ before measurements, and kept at $20 \pm 0.1{ }^{\circ} \mathrm{C}$.

The flat band $\left(\mathrm{E}_{\mathrm{fb}}\right)$ potentials were determined for all materials using impedance measurements by EIS at the frequency range from $20 \mathrm{kHz}$ to $1 \mathrm{~Hz}$ for 10 points per decade with $10 \mathrm{mV}$ point-to-point amplitude of the AC signal.

Photoelectrochemical measurements were carried out in a three-electrode glassy cell with a high transmittance quartz window. The studied samples, with an active surface area of $0.8 \pm 0.1 \mathrm{~cm}^{2}$, remained in the same electrolyte and under conditions as mentioned above. The light source was a $150 \mathrm{~W}$ xenon lamp (Osram XBO 150, Quantum Desing, Darmstadt, Germany) equipped with an AM1.5 filter and an automatic shutter that opened every $10 \mathrm{~s}$.

\subsection{Chemicals}

All reagents used in the electrochemical electrolyte preparation were of analytical grade: $\mathrm{CoCl}_{2} \cdot 6 \mathrm{H}_{2} \mathrm{O}\left(\mathrm{POCH}\right.$, Gliwice, Poland), $\mathrm{K}_{2} \mathrm{SO}_{4}, \mathrm{H}_{3} \mathrm{PO}_{4}, \mathrm{NaNO}_{3}$, ethylene glycol (POCH, Gliwice, Poland), and Ti foils ( $99.5 \%$ metals base, Alfa Aesar, Kandel, Germany). In all experiments, triple distilled water was used. 


\section{Results}

\subsection{Preparation of the Electrode Materials}

Nanostructures of titanium dioxide were prepared by electrochemical oxidation of the titanium foil $\left(0.25 \mathrm{~mm}\right.$ thick, annealed, area $\left.2 \times 2 \mathrm{~cm}^{2}\right)$ in the electrolyte containing $0.27 \mathrm{M}$ $\mathrm{NH}_{4} \mathrm{~F}$ in a solution containing $5 \mathrm{vol} \%$ of water, $3.5 \mathrm{vol} \%$ of $\mathrm{H}_{3} \mathrm{PO}_{4}(95 \%)$ and $91.5 \mathrm{vol} \%$ of $\mathrm{EG}$, at $40 \mathrm{~V}$ for $2 \mathrm{~h}$ [43]. This process of anodization was performed in a glassy cell with the cooling jacket at $20 \pm 0.1^{\circ} \mathrm{C}$, using a thermostat (Julabo F-12, Seelbach, Germany). Afterwards samples were cleaned in an ultrasonic bath in a 1:1 solution of acetone and isopropanol. Samples were then rinsed with triple distilled water and dried using the hot stream of air. The anodized and cleaned $\mathrm{TiO}_{2}$ films were calcined at $450{ }^{\circ} \mathrm{C}$ for $2 \mathrm{~h}$ in the air (the heating rate was $2.5^{\circ} \mathrm{C} / \mathrm{min}$ ) and cooled freely. The above-mentioned steps allow to create the titania nanotubes $\left(\mathrm{TiO}_{2}-\mathrm{NTs}\right)$ on the surface of titanium [43].

Subsequently, the $\mathrm{TiO}_{2}$-NTs sample was immersed in the $50 \mathrm{~cm}^{3}$ Teflon chamber with a $30 \mathrm{~mL}$ aqueous solution containing: $1.07 \mathrm{~g} \mathrm{CoCl}_{2} \cdot 6 \mathrm{H}_{2} \mathrm{O}, 2.56 \mathrm{~g} \mathrm{NaNO}_{3}$ and $75 \mu \mathrm{L}$ $(35-38 \%) \mathrm{HCl}$. The container was sealed off inside a steel autoclave and placed in an oven at $100{ }^{\circ} \mathrm{C}$ for $24 \mathrm{~h}$. After this hydrothermal treatment, the sample was taken out, rinsed several times in a solution of 1:1 acetone/isopropyl alcohol and in distilled water. This process was performed to obtain $\mathrm{Co}$-doped titania nanotubes $\left(\mathrm{Co}-\mathrm{TiO}_{2}-\mathrm{NTs}\right)$. The third sample was prepared by anodization of the Ti plate and hydrothermal modification finally followed by thermal treatment in a tube furnace in contact with air at $450{ }^{\circ} \mathrm{C}$ for $2 \mathrm{~h}$. This sample is labeled as $\mathrm{Co}-\mathrm{TiO}_{2}$.

\subsection{Morphology and Composition of the Samples}

Scanning Electron Microscope and Energy Dispersive X-Ray Analysis

The imaging of the titanium surface covered with nanotubes is most often carried out using scanning electron microscopy. The use of SEM is effective due to the good conductivity of the semiconducting titanium dioxide [44]. Imaging allows for determining the length of nanotubes, their wall thickness, the diameter of pores, and interpose distances [44]. Today, it is widely used to analyze surfaces by means of scanning electron microscopy. In Figure 1 is an image obtained from the scanning electron microscope showing pure $\mathrm{TiO}_{2}$ nanotubes and modified samples. On the left side, marked as $\mathrm{A}$, is an image of pure $\mathrm{TiO}_{2}$ nanotubes. The observed neighboring tubes' edges touch each other. The diameters are marked in the picture and do not exceed $120 \mathrm{~nm}(117,87,102 \mathrm{~nm})$. The tubular shapes are slightly irregular. They probably reflect the arrangement of the rolled plate substrate. This sample was next hydrothermally modified. The image of the modified sample is shown in picture $1 \mathrm{~B}$. As can be seen, the material marked as $\mathrm{Co}-\mathrm{TiO}_{2}-\mathrm{NTs}$ is different from the unmodified sample $1 \mathrm{~A}$. We have separate tubular shapes with slightly greater diameters. Tubes do not touch their edges. Such an electrode material should have a higher real surface area, and therefore higher currents. Now let us look at what happens to the electrode material if we thermally modify $\left(450{ }^{\circ} \mathrm{C}, 2 \mathrm{~h}\right)$ the sample $\mathrm{Co}-\mathrm{TiO}_{2}-\mathrm{NTs}$ (Figure 1B) to obtain sample Co- $\mathrm{TiO}_{2}$ (Figure 1C). The change is drastic. The nanotubes cease to exist and are sealed together-we observe an intricate lace, but not nanotubes any

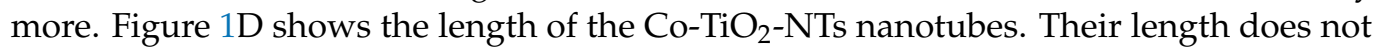
exceed $215 \mu \mathrm{m}$.

The chemical composition of the sample was estimated by the EDX method. Titanium plates covered with oxide layers were analyzed thoroughly. Two samples showed the presence of small amounts of cobalt. EDX examination of the sample after hydrothermal modification $\mathrm{Co}-\mathrm{TiO}_{2}-\mathrm{NTs}$ showed the presence of $\sim 0.1$ at $\%$ of Co. Sample Co-TiO contained also $\sim 0.1$ at $\%$ of Co. The distribution of elements is presented in Supplementary Materials (Figure S1). Due to the low content of Co, scanning by EDX does not allow for a reliable measurement of this dopant distribution. As is shown below, both electrodes with traces of cobalt have catalytic and photoelectrocatalytic enhanced activity towards water oxidation in comparison with pure $\mathrm{TiO}_{2}$ nanotubes. 

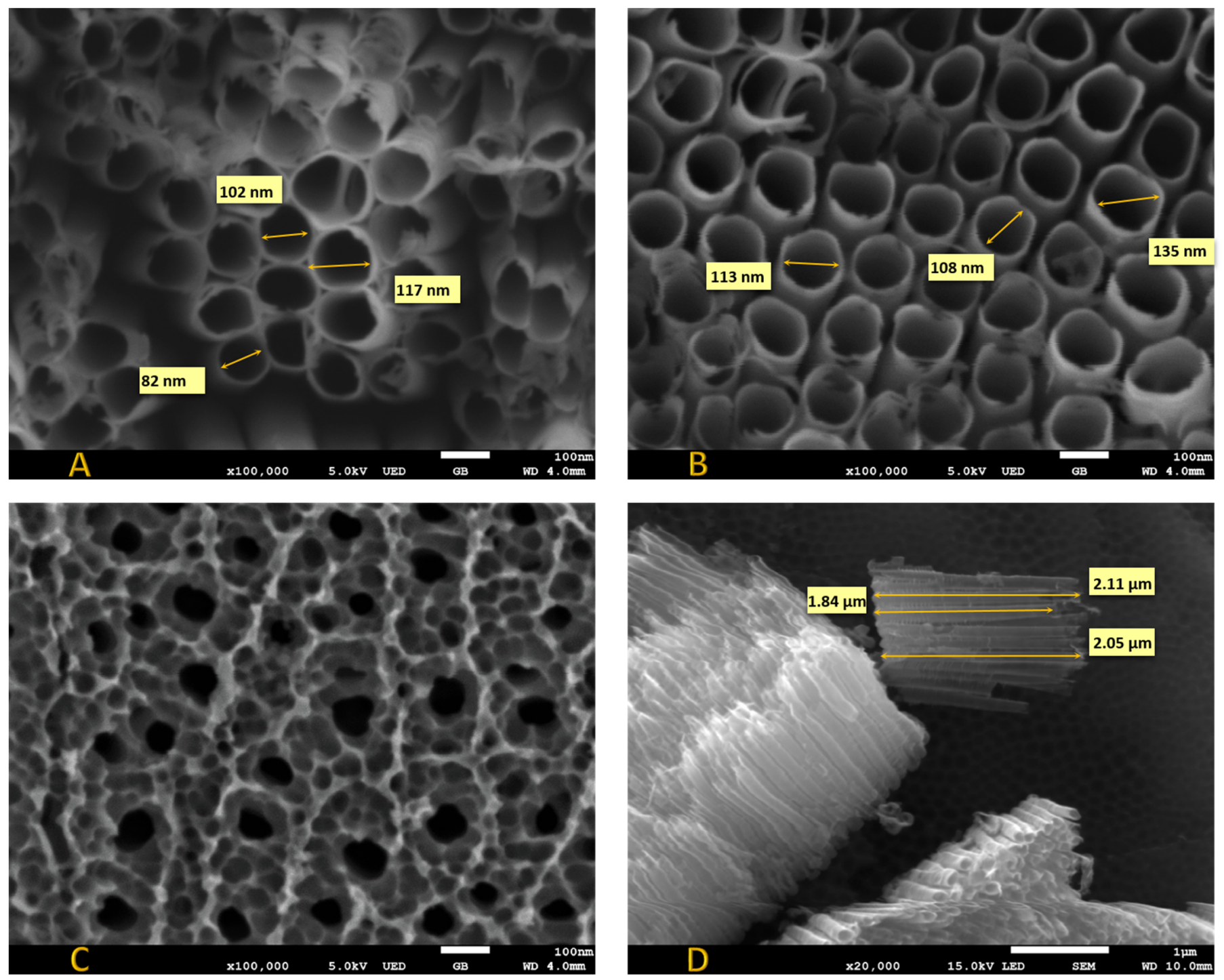

Figure 1. SEM images: (A) pure $\mathrm{TiO}_{2}$ nanotubes $\mathrm{TiO}_{2}-\mathrm{NTs}$; (B) sample hydrothermally modified Co- $\mathrm{TiO}_{2}-\mathrm{NTs}$; (C) sample $\mathrm{Co}-\mathrm{TiO}_{2}$ after final thermal treatment $\left(450{ }^{\circ} \mathrm{C}, 2 \mathrm{~h}\right)$; and (D) length of nanotubes for $\mathrm{Co}-\mathrm{TiO}_{2}-\mathrm{NTs}_{\text {. }}$

\subsection{Structure}

\subsubsection{X-Ray Powder Diffraction}

XRD analysis was performed to determine the phase composition, crystallinity, and crystallite size of the prepared samples. The results are shown in Figure 2. The diffraction reflections at $35^{\circ}, 40.1^{\circ}$, and $53^{\circ}$ correlate to the (100), (101), and (102) planes of the hexagonal closest packed titanium [45], respectively. All obtained $\mathrm{TiO}_{2}$ nanostructures consisted of the pure anatase phase without the brookite or rutile phase. This is confirmed by the observed at $25.3^{\circ}, 37.9^{\circ}, 38.4^{\circ}, 48^{\circ}, 54^{\circ}$, and $55^{\circ}$ corresponding to Miller indices (101), (004), (112), (200), (105), and (211), respectively [46]. 


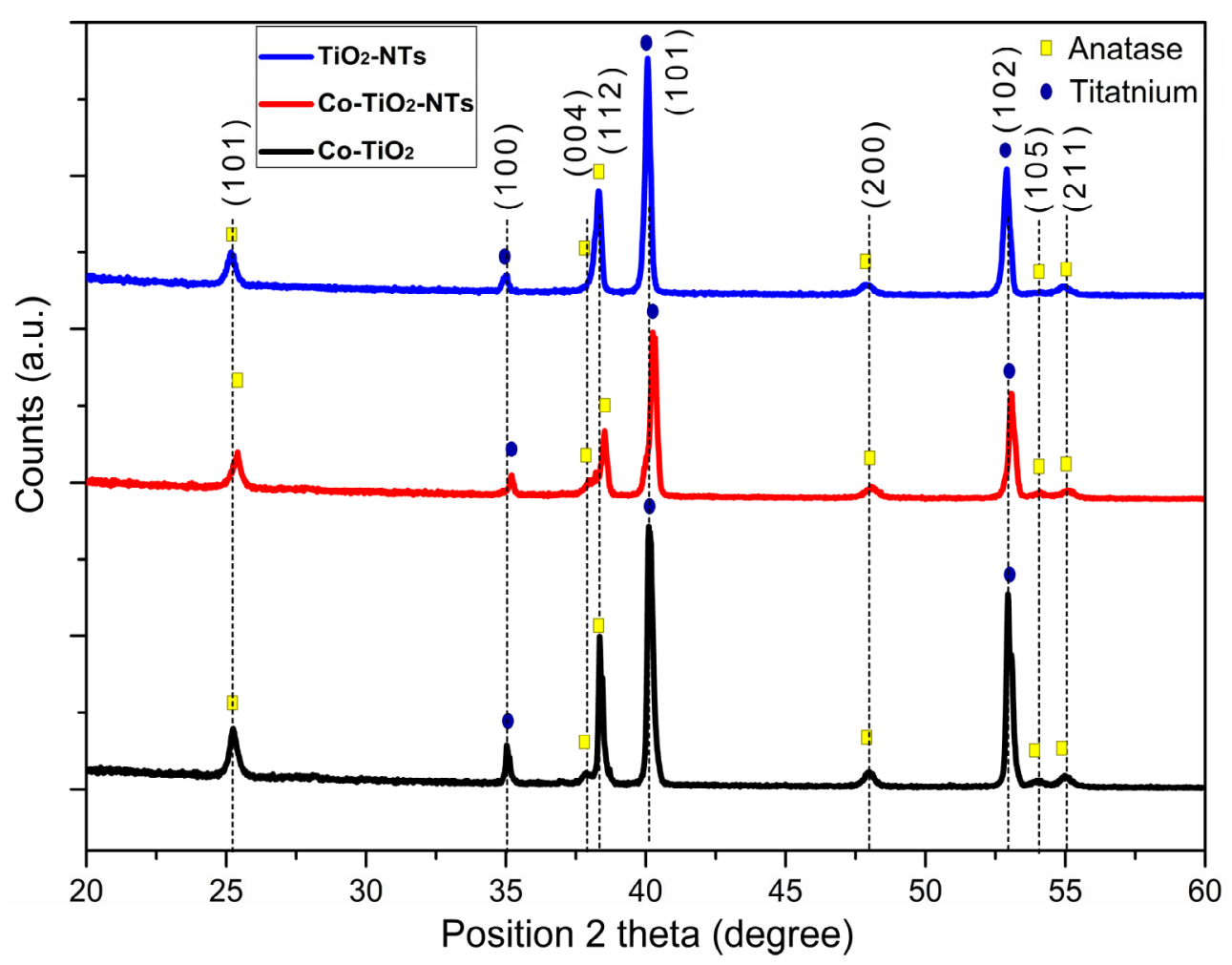

Figure 2. Comparison of XRD patterns of titanium samples covered with $\mathrm{TiO}_{2}$ nanotubes pure and with cobalt doping.

Based on the Scherrer formula, defined by the equation:

$$
D_{h k l}=\frac{K \lambda}{B_{k} \cos \theta}
$$

where $K$ is a dimensionless shape factor $(K=0.9), \lambda$ is the $C u K \alpha$ radiation $X$-ray wavelength, $B_{k}$ is the line broadening at half the maximum intensity (FWHM) [47], mean crystallite sizes for selected crystallographic planes were determined, and are summarized in Table 1.

There are no reflections that identify cobalt compound or Co metal. According to Peng Jiang et al. [38], no changes in XRD analysis were observed for low atomic cobalt contents. All prepared samples receive nanometer sizes. However, for the Co-doped $\mathrm{TiO}_{2}$, a slight increase in crystallite size in the direction perpendicular to the (112) plane was observed. This phenomenon may affect the frequency shifting and broadening of Raman peaks due to the phonon confinement [48]. It cannot be excluded that small quantities of cobalt had built into the nanostructure of $\mathrm{TiO}_{2}$.

Table 1. Mean crystallite sizes calculated from the Scherrer's equation based on achieved XRD patterns for $\mathrm{TiO}_{2}-\mathrm{NTs}$, $\mathrm{Co}-\mathrm{TiO}_{2}$-NTs and $\mathrm{Co}-\mathrm{TiO}_{2}$.

\begin{tabular}{ccccc}
\hline Sample & $\mathbf{D}_{\mathbf{1 0 1}}(\mathbf{n m})$ & $\mathbf{D}_{\mathbf{1 1 2}}(\mathbf{n m})$ & $\mathbf{D}_{\mathbf{2 0 0}}(\mathbf{n m})$ & $\mathbf{D}_{\mathbf{2 1 1}}(\mathbf{n m})$ \\
\hline $\mathrm{TiO}_{\mathbf{2}}-\mathrm{NTs}$ & 18.2 & 28.2 & 16.5 & 25.5 \\
$\mathrm{Co}^{-} \mathrm{TiO}_{\mathbf{2}}-\mathrm{NTs}$ & 15.3 & 41.1 & 14.6 & 17.5 \\
$\mathrm{Co}^{-\mathrm{TiO}_{2}}$ & 19.7 & 34.6 & 15.0 & 13.3 \\
\hline
\end{tabular}

\subsubsection{Raman Spectroscopy}

Raman spectra of $\mathrm{TiO}_{2}-\mathrm{NTs}, \mathrm{Co}-\mathrm{TiO}_{2}-\mathrm{NTs}$, and $\mathrm{Co}-\mathrm{TiO}_{2}$ samples recorded in the spectral range of 100-1200 $\mathrm{cm}^{-1}$ are presented in Figure 3. The Raman bands centered at 144, $197,392,515$, and $633 \mathrm{~cm}^{-1}$ corresponds to $\mathrm{E}_{\mathrm{g}}(1), \mathrm{E}_{\mathrm{g}}(2), \mathrm{B}_{1 \mathrm{~g}}, \mathrm{~A}_{1 \mathrm{~g}}$, and $\mathrm{E}_{\mathrm{g}}$ (3) modes of the anatase phase, respectively. The origin of the $\mathrm{E}_{\mathrm{g}}$ bands can be attributed to the sym- 
metric stretching vibration of $\mathrm{O}-\mathrm{Ti}-\mathrm{O}$, while the $\mathrm{B}_{1 \mathrm{~g}}$ band corresponding to the symmetric bending vibration of $\mathrm{O}-\mathrm{Ti}-\mathrm{O}$ and $\mathrm{A}_{1 \mathrm{~g}}$ mode can be assigned to the antisymmetric bending vibration of Ti-O-Ti in the anatase phase. The intense sharp band centered near $144 \mathrm{~cm}^{-1}$ corresponds to an external symmetric vibration and confirms the formation of long-range order anatase phase $[48,49]$. The position of this band correlates to the nanocrystalline grain size and the up-shift of its position can be observed with decreasing of the grain size [50,51]. The broadening and up-shifted position of the $\mathrm{E}_{\mathrm{g}}$ (1) mode observed for $\mathrm{Co}-\mathrm{TiO}_{2}-\mathrm{NTs}$ and $\mathrm{Co}-\mathrm{TiO}_{2}$ samples may be assigned to structural defects resulting from the doping of $\mathrm{TiO}_{2}$ with Co ions.

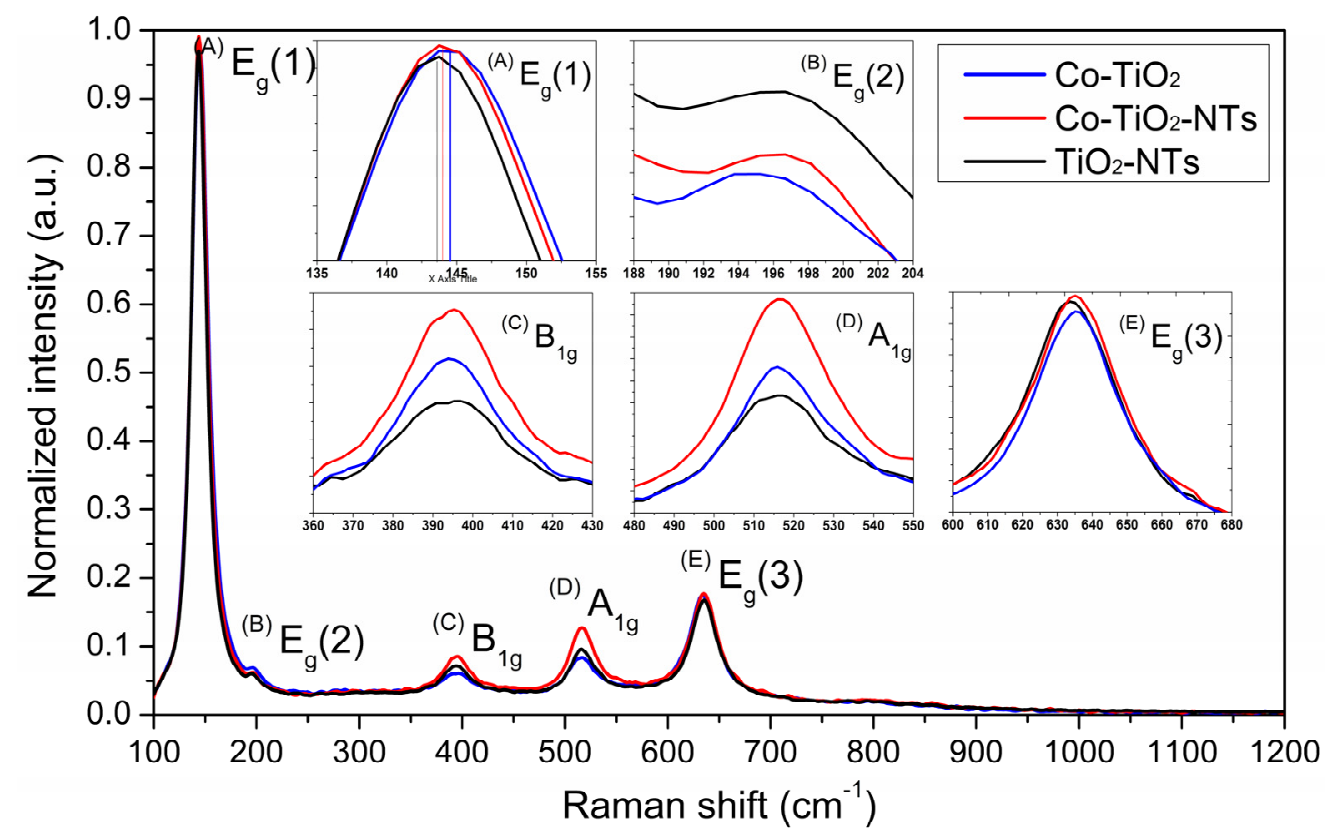

Figure 3. Raman spectra of pure titania nanotubes and Co-doped $\mathrm{TiO}_{2}$ samples. (A-E) typical modes of the anatase phase.

\subsubsection{X-ray Photoelectron Spectroscopy}

Helpful information about the chemical structure of modified titania is available from XPS studies. The $\mathrm{TiO}_{2}-\mathrm{NTs}$ and $\mathrm{Co}-\mathrm{TiO}_{2}-\mathrm{NTs}$ samples were examined and compared. The third sample, $\mathrm{Co}-\mathrm{TiO}_{2}$, was not photoactive, and thus was not included in XPS tests. The survey spectra from $0 \mathrm{eV}$ to $1350 \mathrm{eV}$ showed the presence of titanium, carbon, oxygen,

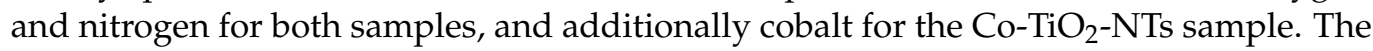
survey spectra made with the $150 \mathrm{eV}$ transition energy showed the difference between the $\mathrm{TiO}_{2}$-NTs and $\mathrm{Co}-\mathrm{TiO}_{2}-\mathrm{NTs}$ samples (Figure 4). On the latter, the Co2p peaks and the Auger Co LMM peak $(713 \mathrm{eV})$ are noticeable, which proves the presence of cobalt. Both samples contain titanium, carbon, oxygen, and nitrogen. High-resolution scans were performed in the range of Ti2p, C1s, O1s, N1s, and Co2p. A pass energy of $35 \mathrm{eV}$ and 50 repetitions were used. The carbon came from impurities (adventitious carbon) and was used to calibrate the measurement. A small amount of nitrogen may be from the substrates used to produce the samples and is observed in similar measurements [38].

Titanium appears as a doublet of the Ti2 $\mathrm{p}_{1 / 2}(464.6 \mathrm{eV})$ and Ti2 $\mathrm{p}_{3 / 2}(458.9 \mathrm{eV})$ peaks. These energies testify to the presence of titanium in the +4 oxidation state in titania [52]. The titanium peaks are identical for the $\mathrm{TiO}_{2}-\mathrm{NTs}$ and $\mathrm{Co}-\mathrm{TiO}_{2}-\mathrm{NTs}$ samples, not shown.

The amount of cobalt is low compared to the rest of the elements, but it is detectable and analyzable. The measurement clearly shows the Co2p5 and Co2p3 doublet and the so-called shake up peaks just after the main peaks [53]. The energy difference between the doublet peaks for Co is $15.4 \mathrm{eV}$ and is consistent with the XPS databases [54,55].

Measurement for $\mathrm{Co} 2 \mathrm{p}_{3 / 2}$ in cobalt oxide is $780.4 \mathrm{eV}$, which is in agreement with the binding energy of cobalt. The presence of shake up peaks is confirmed in the literature 
and proves the existence of $\mathrm{Co}^{2+}[38,56]$. The estimated cobalt atomic percentage from the XPS measurements was $\sim 0.4$ at $\%$ at $780.4 \mathrm{eV}$ corresponding to $\mathrm{Co} 2 \mathrm{p}_{3 / 2}$, whereas EDX measurements show $\sim 0.1$ at \%. Higher values of Co content from XPS measurements may suggest that cobalt is accumulated mostly in the near-surface area. It was thus confirmed by XPS that the $\mathrm{Co}-\mathrm{TiO}_{2}-\mathrm{NTs}$ sample contained cobalt in the +2 valence state, and although there was relatively little of it, it was detectable.
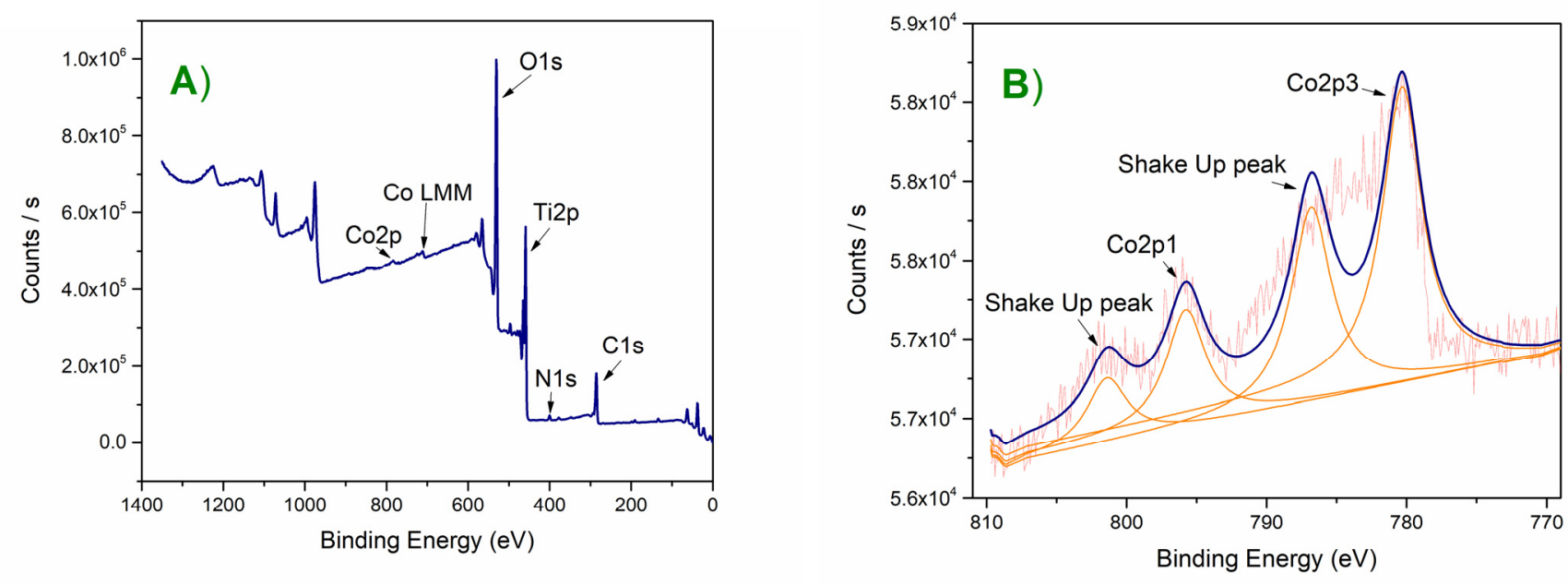

Figure 4. (A) Survey spectrum. It is almost identical for both samples. The Co- $\mathrm{TiO}_{2}-\mathrm{NTs}$ sample additionally reveals cobalt in the form of Co2p and Co LMM peaks; (B) detailed cobalt spectrum for Co- $\mathrm{TiO}_{2}-\mathrm{NTs}$.

Our results are consistent with reported data on powder titania modified during the hydrothermal procedure by a small amount of Co [38]. The authors presented a DFT theory-based calculated electronic structure of Co-doped $\mathrm{TiO}_{2}$ and indicated that impurity states are introduced into the forbidden band due to the low concentration cobalt doping. They documented that these impurity states are beneficial to the enhancement of visible light absorption and the improvement of photocatalysis efficiency of powder Co-modified titania as experienced with our titania nanotubes.

\subsection{Reflectance UV-Vis Spectroscopy}

In Figure $5 \mathrm{~A}-\mathrm{C}$, the absorbance, reflectance, and Tauc plot are given for the obtained materials, respectively. As can be seen, obtained electrodes in the ultraviolet region have the highest absorbance, which is typical for $\mathrm{TiO}_{2}$ materials. Moreover, the wide absorption band with the maximum at $550 \mathrm{~nm}$ could originate from the presence of sub-bandgap states caused by the structure of the titania nanotube that can trap radiation inside the tube [57]. In the case of the $\mathrm{Co}-\mathrm{TiO}_{2}$ sample, the absorbance in the visible range $(450-700 \mathrm{~nm})$ is characterized by a lower intensity in comparison with the bare $\mathrm{TiO}_{2}$ and $\mathrm{Co}-\mathrm{TiO}_{2}-\mathrm{NTs}$. This means that absorption in this range of visible light, as clearly seen, is more intense for the samples with the nanotubular structure. $\mathrm{The}^{\mathrm{TiO}}{ }_{2}$ material characterized by a non-tubular structure does not exhibit this feature. In the case of $\mathrm{Co}_{-} \mathrm{TiO}_{2}-\mathrm{NTs}$, the redshift of the absorption edge is observed, which is advantageous for the materials expected to be photoactive under visible light illumination. The dopant presence is responsible for changes, very likely due to impurities formed in between the forbidden energy bandgap [38]. On the other hand, physicochemically bond water is also supposed to cause red shift [58]. Taking into account the fact that $\mathrm{Co}-\mathrm{TiO}_{2}-\mathrm{NTs}$ were not subjected to a thermal process after hydrothermal treatment, the second argument seems to be very likely prevailing. 
Based on the Tauc plot, the bandgap energy values were determined and are $2.85 \mathrm{eV}$, $2.92 \mathrm{eV}$, and $2.99 \mathrm{eV}$ for $\mathrm{Co}-\mathrm{TiO}_{2}, \mathrm{Co}-\mathrm{TiO}_{2}-\mathrm{NTs}$, and pure $\mathrm{TiO}_{2}$, respectively. Therefore, both modified materials were characterized by a slightly narrower bandgap energy in comparison with pure titania nanotubes. Although $\mathrm{Co}-\mathrm{TiO}_{2}$ has the smallest energy bandgap, it has the worst photoelectrochemical activity compared to the other materials. The reason for this is very likely the lack of a tubular structure and low absorption in the visible light range as recorded on UV-Vis spectra (see Figure 5A).

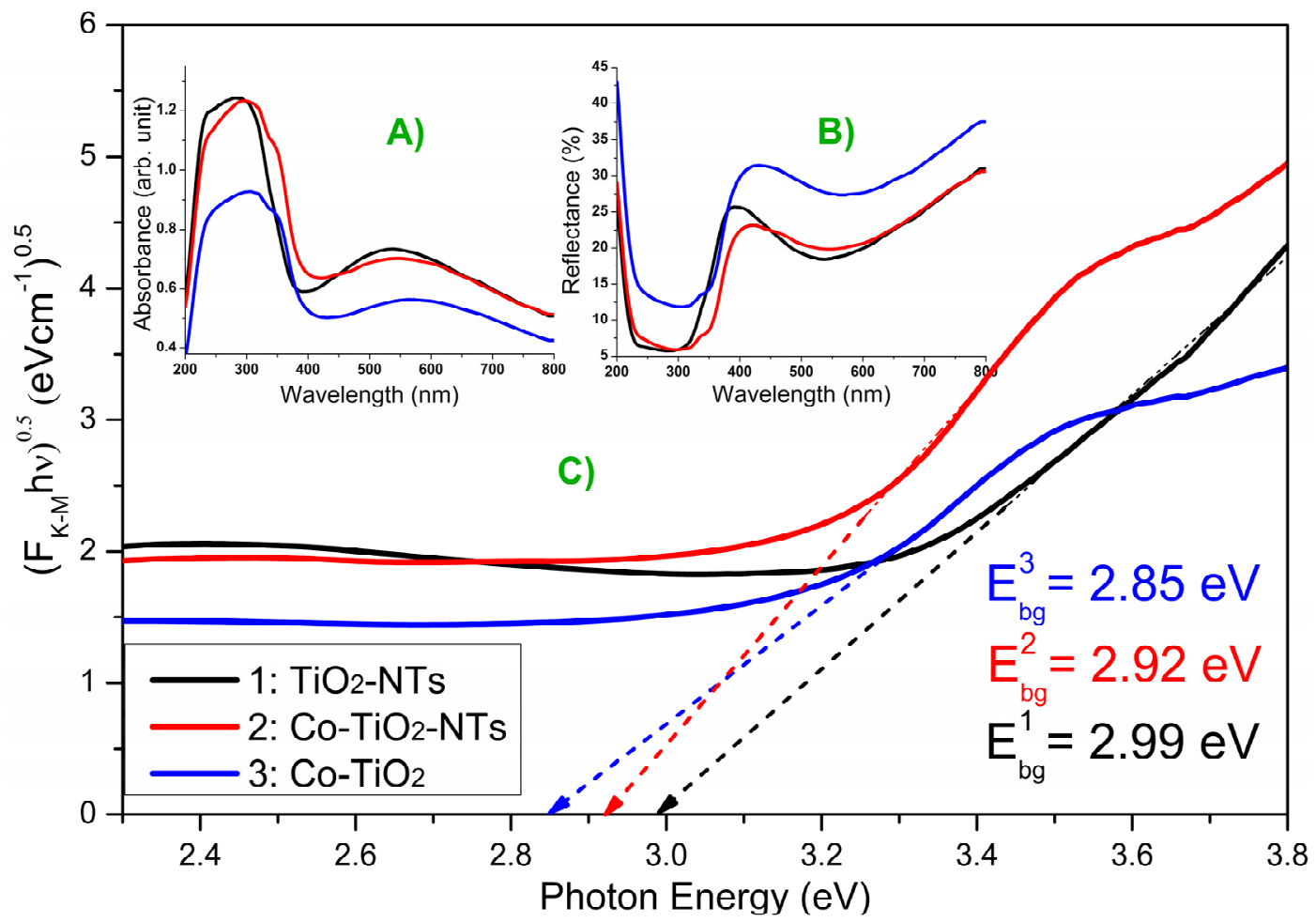

Figure 5. (A) Absorbance, (B) reflectance spectra, and (C) Tauc plot for samples $\mathrm{TiO}_{2}-\mathrm{NTs}, \mathrm{Co}-\mathrm{TiO}_{2}-\mathrm{NTs}_{\mathrm{S}} \mathrm{Co}-\mathrm{TiO}_{2}$.

\subsection{Electrochemical and Photoelectrochemical Properties}

The electrode materials $\mathrm{TiO}_{2}-\mathrm{NTs}, \mathrm{Co}-\mathrm{TiO}_{2}-\mathrm{NTs}$, and $\mathrm{Co}-\mathrm{TiO}_{2}$ were subjected to electrochemical studies in the dark in the potential range from $-0.7 \mathrm{~V}$ to $1.3 \mathrm{~V}$ versus $\mathrm{Ag} / \mathrm{AgCl} / 0.1 \mathrm{M} \mathrm{KCl}$ in $0.1 \mathrm{M} \mathrm{K}_{2} \mathrm{SO}_{4}$. Polarization towards high anode potentials shows whether there are differences in the threshold potentials for oxidation of the water molecule. As you can see, the course of the linear sweep voltammetry curves differs (Figure 6). The threshold potentials $\mathrm{E}_{\text {th }}$ have been determined and their values increase for the electrodes in the order $\mathrm{Co}-\mathrm{TiO}_{2}-\mathrm{NTs}<\mathrm{Co}-\mathrm{TiO}_{2}<\mathrm{TiO}_{2}-\mathrm{NTs}$ with $100 \mathrm{mV}$ lowering of the $\mathrm{E}_{\text {th }}$ value for Co-doped nanotubes.

As can be seen, the introduction of cobalt ions into the structure of titanium dioxide, as well as morphological changes after modification by the hydrothermal method, definitely affect the electrochemical properties of the new systems. The environment of cobalt ions in the structure is to some extent similar to that of ordinary cobalt oxide compounds. Such compounds belong to a group known for their catalytic properties in relation to the oxidation of water molecules [59]. Undoubtedly, both electrodes containing a small amount of cobalt catalyze the oxidation of water to molecular oxygen. The decrease in the water oxidation threshold potential $E_{t h}$ for the modified electrode indicates the effectiveness of the hydrothermal process. 


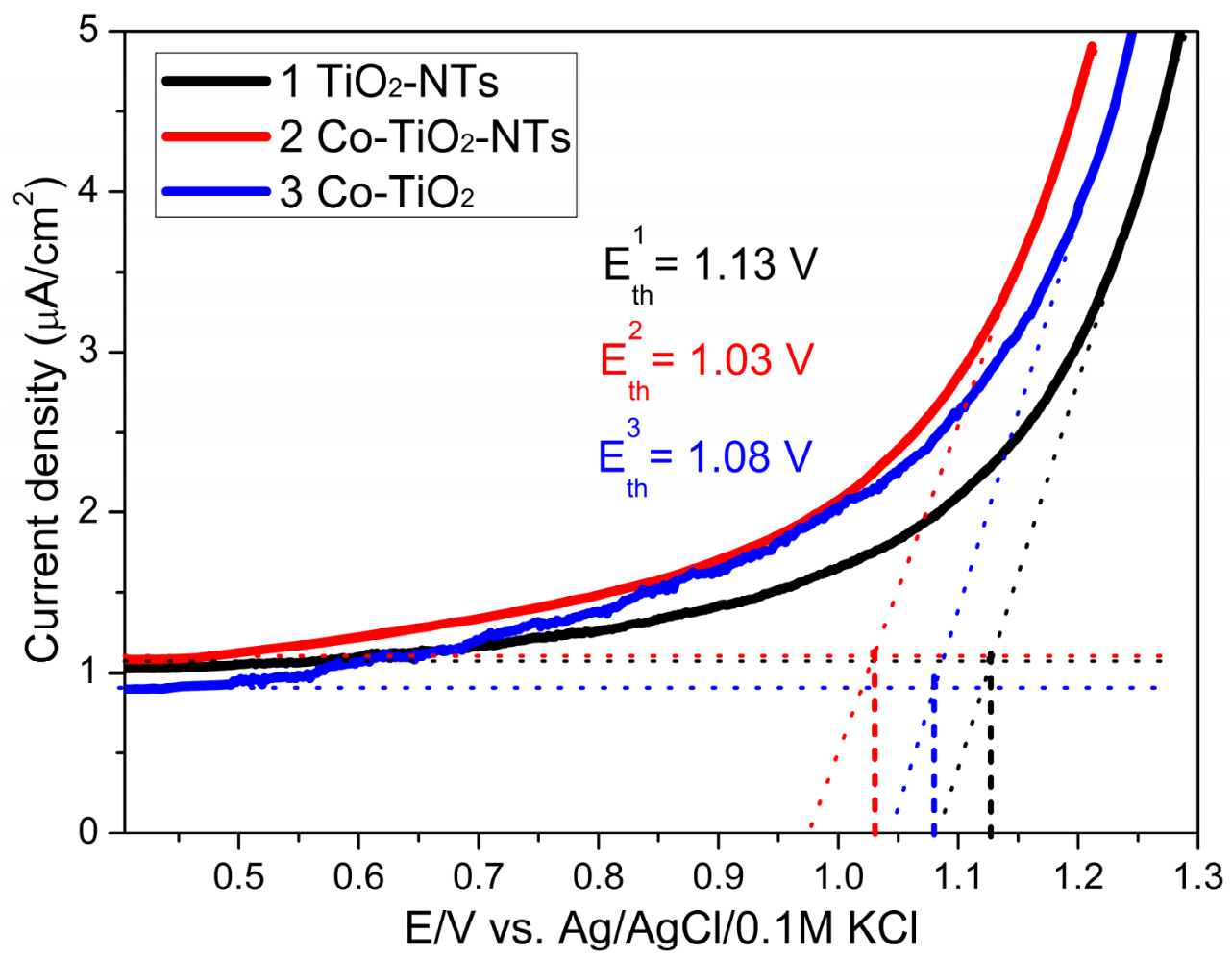

Figure 6. Linear sweep voltammetry (LSV) curves obtained for samples $\mathrm{TiO}_{2}-\mathrm{NTs}, \mathrm{Co}-\mathrm{TiO}_{2}-\mathrm{NTs}$, and $\mathrm{Co}-\mathrm{TiO}_{2}$, used for the evaluation of the water oxidation threshold potential $\mathrm{E}_{\mathrm{th}}$, sweep rate $50 \mathrm{mV} \cdot \mathrm{s}^{-1}$.

$\mathrm{TiO}_{2}$ nanotubes are known for their cathode potential activity. Their typical course of $\mathrm{CV}$ curves obtained for pure and modified titania are shown in Figure 7A-C. The $\mathrm{CV}$ curves obtained for different sweep rates of polarization allow the diagnosis of the reaction mechanism. Linear regression for changes in current with the square root of the polarization sweep rate indicates diffusive process control. When current intensity changes linearly with the polarization rate $v$, one deals with kinetic process control, and the charge transfer reaction is surface limited (see Figure 7D-F). However, the most important outcome from these simple polarization measurements is the possibility of comparing the effective current densities. These values are calculated in relation to the geometric surface area. At the same chosen potential $(-0.5 \mathrm{~V})$, the highest cathode currents were recorded for the $\mathrm{Co}-\mathrm{TiO}_{2}-\mathrm{NTs}$ electrode, and the lowest were recorded for the $\mathrm{Co}-\mathrm{TiO}_{2}$ electrode. Considering the microscopic morphology studies showing that each nanotube has a free surface along its entire length, and direct contact between the tubes is almost absent for the $\mathrm{Co}-\mathrm{TiO}_{2}-\mathrm{NTs}$ material, this condition compared to the pure $\mathrm{TiO}_{2}-\mathrm{NTs}$ and calcined $\mathrm{Co}-\mathrm{TiO}_{2}$ represents an increased real surface area. Hence, the recorded current for $\mathrm{Co}^{-} \mathrm{TiO}_{2}-\mathrm{NTs}$ is the highest. The lowest current densities are recorded for electrodes after final calcination following hydrothermal modification. This material is devoid of a nanotubular structureit is the result of calcination. The $\mathrm{Co}-\mathrm{TiO}_{2}$ sample has an undeveloped specific surface area, and thus the current density related to the geometric surface area is lower. Thus, the research on polarization in terms of cathode potentials confirmed the typical activity of $\mathrm{TiO}_{2}$ nanotubes, as was reported in Ref. [60]. Moreover, it allowed us to assess the state of surface development for a hydrothermally modified electrode. The modification was considered to increase the real surface area due to hydrothermal treatment. 

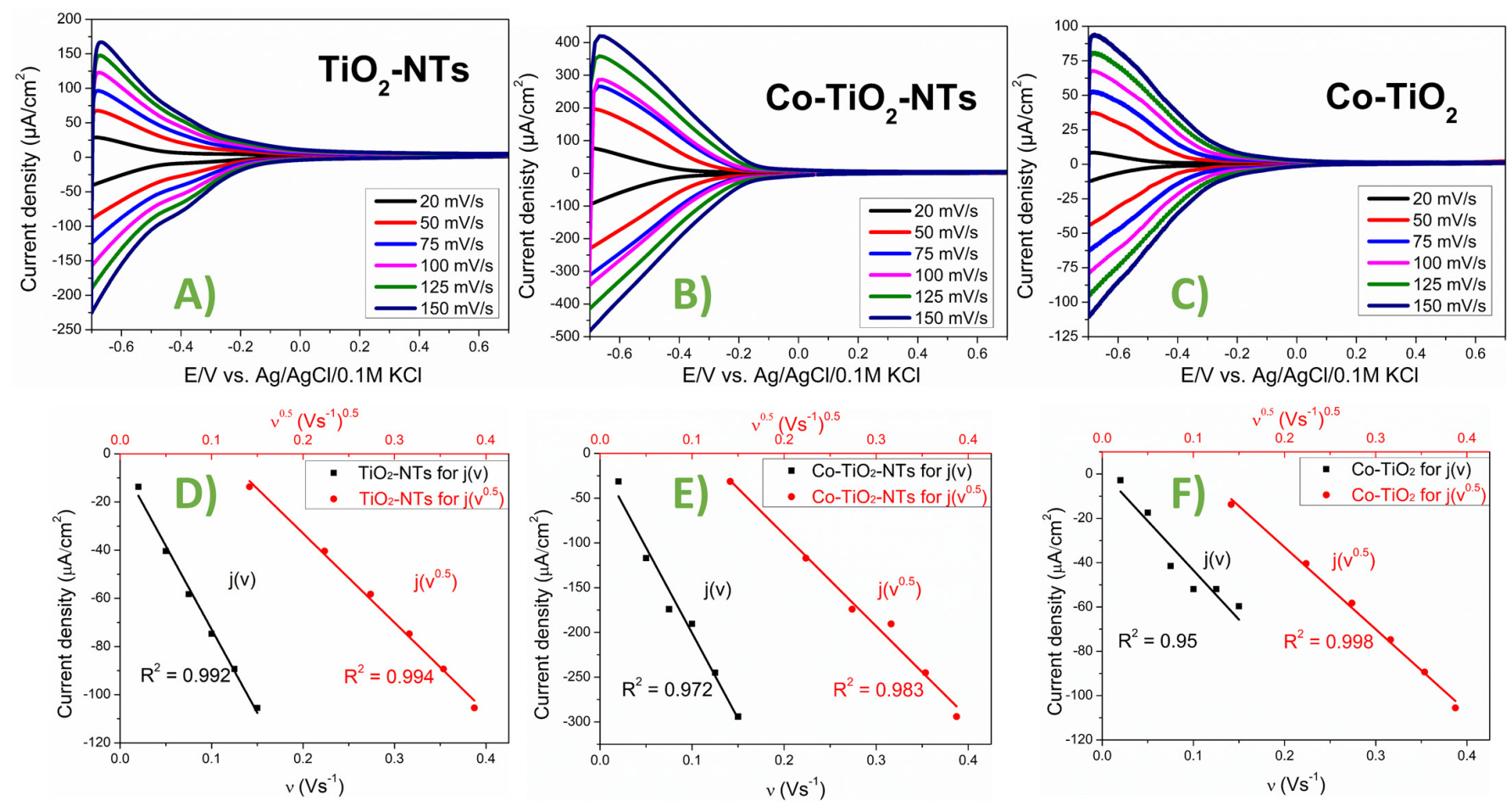

Figure 7. Cyclic voltammetry $(\mathrm{CV})$ curves obtained at varied sweep rates and analysis: $(\mathbf{A}, \mathbf{D}) \mathrm{TiO}_{2}-\mathrm{NTs}$; $(\mathbf{B}, \mathrm{E}) \mathrm{CoTiO}_{2}-\mathrm{NTs}$; (C,F) $\mathrm{Co}-\mathrm{TiO}_{2}$.

Titanium dioxide belongs to the n-type semiconductors. Any changes in structuredoping, the presence of surface modifying substances-will influence the position of the measured value of the flat band potential, the most important value characteristic for the semiconductor electrode [61].

The flat band potential $\mathrm{E}_{\mathrm{fb}}$ was determined for three electrodes: $\mathrm{TiO}_{2}-\mathrm{NTs}, \mathrm{Co}-\mathrm{TiO}_{2}-$ $\mathrm{NTs}$, and $\mathrm{Co}-\mathrm{TiO}_{2}$ materials. Electrochemical impedance spectroscopy was used to measure the impedance of the polarized samples under stationary conditions at a frequency range from $20 \mathrm{kHz}$ to $1 \mathrm{~Hz}$, and $\mathrm{AC}$ signal amplitude $10 \mathrm{mV}$. Examples are gathered in Figure $8 \mathrm{~A}-\mathrm{C}$. The impedance functions presented in the figures are of a typical capacitive character, the course of the function is an almost vertical line, slightly rotated, in line with the presence of $C P E$ (constant phase element), which is neglected here. The capacitance $C$ values were calculated for frequencies: $1 \mathrm{~Hz}, 100 \mathrm{~Hz}$, and $1000 \mathrm{~Hz}$ using the simple relation: $-Z^{\prime \prime}=(j \omega C)^{-1}$, where $C$ is the capacitance, $Z^{\prime \prime}$ is the imaginary part of the impedance function, $\omega$ is the angular frequency, $j=\sqrt{-1}$.

The $\mathrm{E}_{\mathrm{fb}}$ values were determined in accordance with the Mott-Schottky function, using $C$ values extracted from the impedance measurements. The results are presented in Figure 8D-F. Table 2 gathers evaluated flat band potential for different materials. As can be seen, doping nanotubes with cobalt by hydrothermal treatment changes the effective flat band potential significantly-the difference is about $200 \mathrm{mV}$ towards anodic values. This change will be important for the course of the electrode reactions and the availability of the electrons in the conduction band.

Table 2. Flat band potential values for selected frequency for pure and Co-doped $\mathrm{TiO}_{2}$ samples.

\begin{tabular}{cccc}
\hline Sample & $\mathbf{E}_{\mathrm{fb}}(\mathbf{V})$ for $\mathbf{1 ~} \mathbf{~ H z}$ & $\mathbf{E}_{\mathrm{fb}}(\mathbf{V})$ for $\mathbf{1 0 0} \mathbf{~ H z}$ & $\mathbf{E}_{\mathrm{fb}}(\mathbf{V})$ for $\mathbf{1 0 0 0} \mathbf{~ H z}$ \\
\hline $\mathrm{TiO}_{2}-\mathrm{NTs}$ & $-0.21 \pm 0.02$ & $-0.22 \pm 0.02$ & $-0.25 \pm 0.02$ \\
$\mathrm{Co}_{-} \mathrm{TiO}_{2}-\mathrm{NTs}$ & $-0.02 \pm 0.02$ & $0.00 \pm 0.02$ & $0.00 \pm 0.02$ \\
$\mathrm{Co}_{\mathrm{TiO}}$ & $0.15 \pm 0.02$ & $0.06 \pm 0.02$ & $0.02 \pm 0.02$ \\
\hline
\end{tabular}



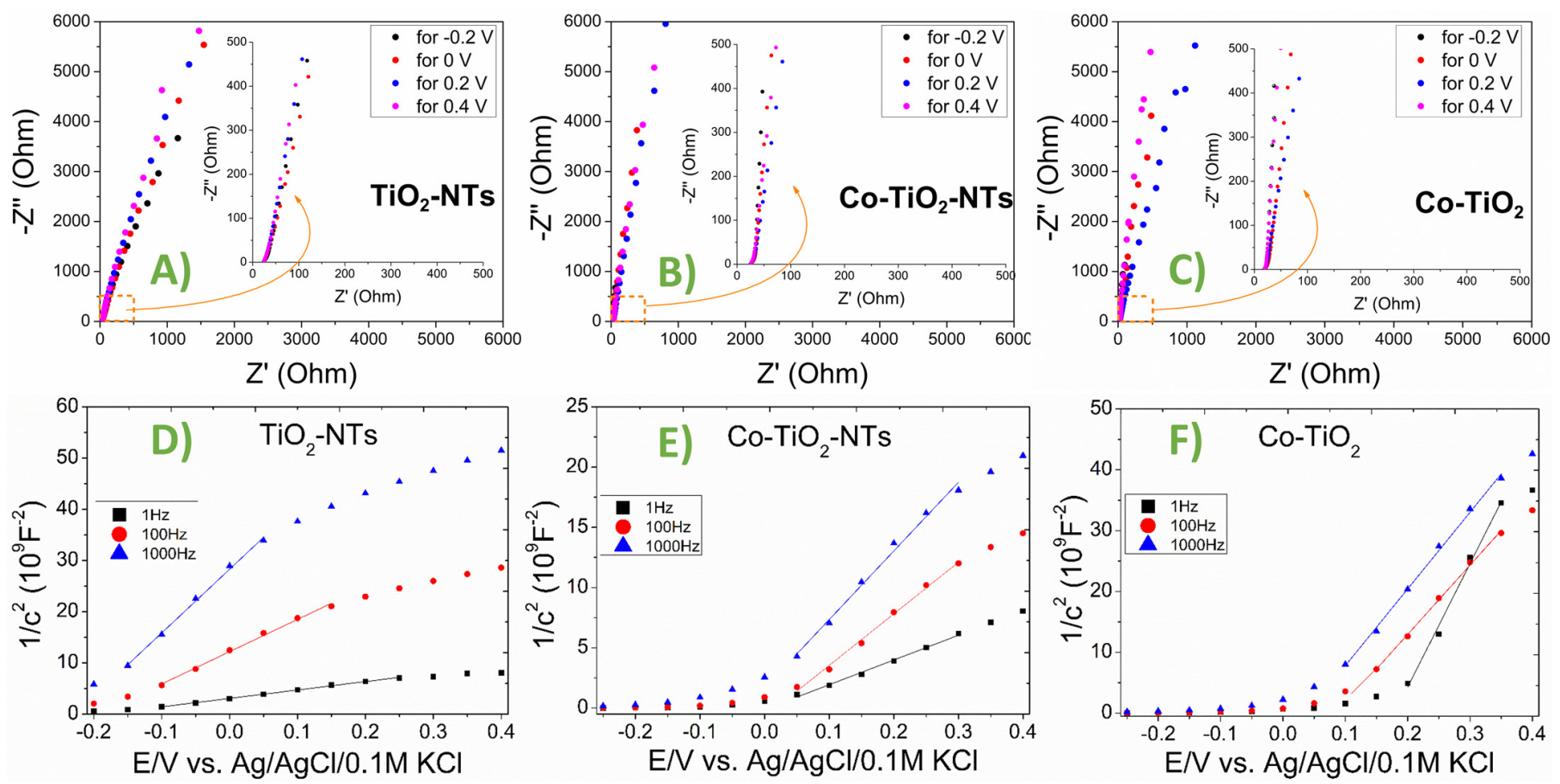

Figure 8. Complex plane impedance plots obtained for: (A) $\mathrm{TiO}_{2}-\mathrm{NTs},(\mathbf{B}) \mathrm{CoTiO}_{2}$ and (C) $\mathrm{Co}-\mathrm{TiO}_{2}$, frequency range $20 \mathrm{kHz}$ to $1 \mathrm{~Hz}$. Mott-Schottky plots for: (D) $\mathrm{TiO}_{2}-\mathrm{NTs}$, (E) $\mathrm{CoTiO}_{2},(\mathbf{F}) \mathrm{Co}-\mathrm{TiO}_{2}$.

According to the aim of our study, the photoelectroactivity of the material in the field of photoanode operation has been investigated. As mentioned and proved above, oxidation of water in dark conditions occurs more easily for the doped electrode, and the $\mathrm{E}_{\text {th }}$ potential is lowered for the $\mathrm{Co}-\mathrm{TiO}_{2}-\mathrm{NTs}$ material. Polarization under solar light illumination was carried out to show how the electrode material behaves as a photoanode.

In Figure 9, the photocurrent generation recorded at a constant potential of $0.5 \mathrm{~V}$ vs. $\mathrm{Ag} / \mathrm{AgCl} / 0.1 \mathrm{M} \mathrm{KCl}$ is given for the pure $\mathrm{TiO}_{2}$ nanotubes and the Co-modified electrodes. Of all the samples, the material labeled as $\mathrm{Co}-\mathrm{TiO}_{2}$ generates the lowest photocurrent. Such weak photoactivity for modified titania prepared by the hydrothermal method and finished by extra is caused by the non-tubular morphology characterized by lower electron lifetimes than the ordered layer, and does not provide good pathways for electron transport $[62,63]$. Additionally, $\mathrm{Co}-\mathrm{TiO}_{2}$ has the lowest absorbance intensity compared to other samples in the VIS region, which is considered a very important factor, influencing photoconversion efficiency. The highest photocurrent was observed for Co$\mathrm{TiO}_{2}$-NTs reaching about $40 \mu \mathrm{A} \cdot \mathrm{cm}^{-2}$ stabilized at $32 \mu \mathrm{A} \cdot \mathrm{cm}^{-2}$ under sunlight illumination.

The difference between the current registered for a sample in the dark and under its illumination $(\Delta j)$ are listed in Table 3 together with the ratio between the current registered for a sample in the dark and under its illumination $\left(j_{l} / j_{d}\right)$ and the ratio between photocurrent and light source optical power (photoresponsivity). 


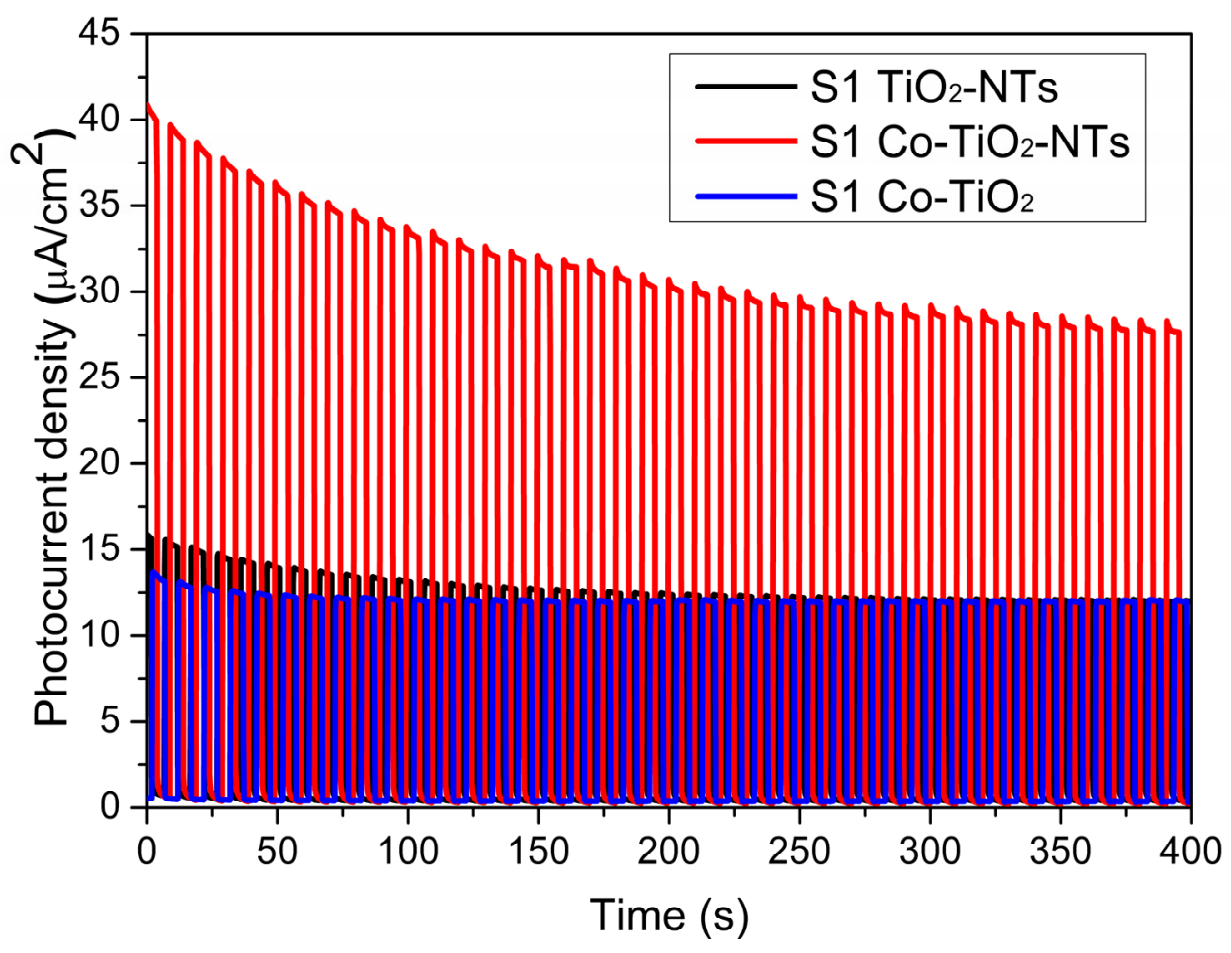

Figure 9. The chronoamperometry curve, showing the photocurrent density, registered for modified and pure titania electrodes at $\mathrm{E}=+0.5 \mathrm{~V}$. Source of light: $150 \mathrm{~W}$ xenon lamp equipped with an AM1.5 filter, light intensity: $100 \mathrm{~mW} \cdot \mathrm{cm}^{2}$.

Table 3. Determined photoresponsivity values from Figure 9, where: $\Delta j$ is the difference between the current registered for a sample in the dark and under its illumination, $j_{l} / j_{\mathrm{d}}$ is the ratio between the current registered for a sample in the dark and under its illumination, and $\Delta j / P$ (photoresponsivity) is the ratio between photocurrent and light source optical power.

\begin{tabular}{|c|c|c|c|}
\hline Sample & $\Delta j\left(\mu \mathrm{A} \cdot \mathrm{cm}^{-2}\right)$ & $j_{l} / j_{\mathrm{d}}$ & $\Delta j / P\left(\mu \mathrm{A} \cdot \mathrm{W}^{-1}\right)$ \\
\hline $\mathrm{TiO}_{2}-\mathrm{NTs}$ & 12.51 & 33.08 & 12.5 \\
\hline $\mathrm{Co}-\mathrm{TiO}_{2}$-NTs & 32.71 & 137.29 & 32.7 \\
\hline Co-TiO 2 & 11.68 & 33.44 & 11.7 \\
\hline
\end{tabular}

LSV measurements were presented also to compare photoactivity of the obtained electrodes. The obtained results are presented in Figure 10. In the early stages, the photocurrent densities in all examined samples increased with increasing potential applied to the photoanode and then stabilized at a potential of around $0 \mathrm{~V}$ vs. $\mathrm{Ag} / \mathrm{AgCl} / 0.1 \mathrm{M}$ $\mathrm{KCl}$. The highest photocurrent generation value was obtained for $\mathrm{Co}-\mathrm{TiO}_{2}-\mathrm{NTs}$. At a potential equal to $+0.2 \mathrm{~V}$, the value of the current density is more than two times higher than the current registered for pure $\mathrm{TiO}_{2}$ nanotubes and sintered $\mathrm{Co}-\mathrm{TiO}_{2}$. Therefore, the Co species on and in the tubular matrix play an important role in the enhanced photocurrent generation (therefore in the case of non-tubular morphology we do not see an improvement in the photocurrent). Thus, the increase in the charge generation is influenced by the presence of $\mathrm{Co}$ and this can be caused by the enhanced light absorption in the visible range, as well as the decrease in the recombination rate and the charge transfer resistance. 

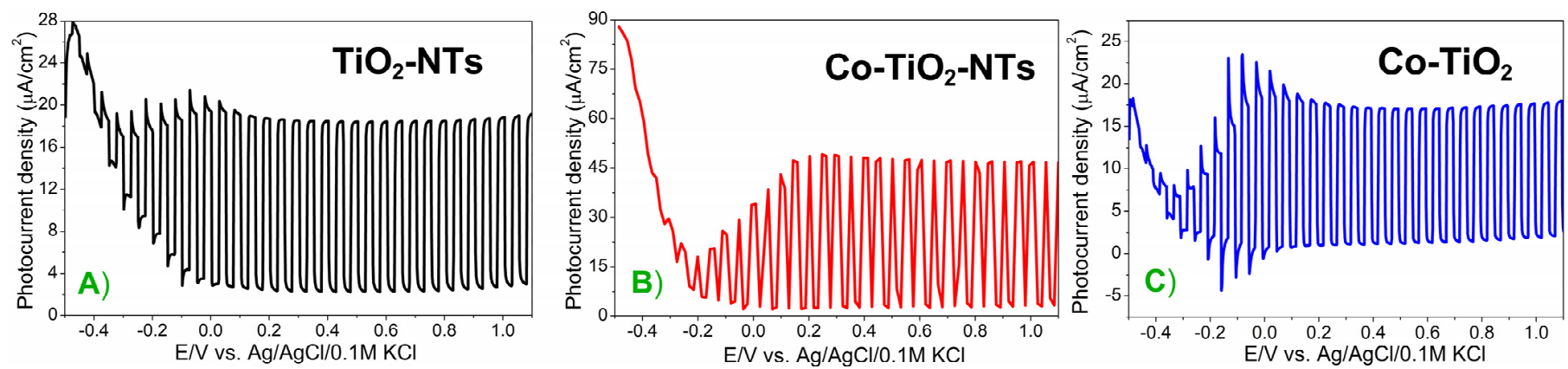

Figure 10. The linear sweep voltammetry curves obtained at a sweep rate $50 \mathrm{mV} \cdot \mathrm{s}^{-1}$ for samples (A) $\mathrm{TiO}_{2}-\mathrm{NTs}$ (black line), (B) $\mathrm{Co}-\mathrm{TiO}_{2}-\mathrm{NTs}$ (red line), (C) $\mathrm{Co}-\mathrm{TiO}_{2}$ (blue line) in the $0.1 \mathrm{M} \mathrm{K}_{2} \mathrm{SO}_{4}$ aqueous electrolyte. Source of light: $150 \mathrm{~W}$ xenon lamp equipped with an AM1.5 filter, light intensity: $100 \mathrm{~mW} \cdot \mathrm{cm}^{2}$.

The low energy bandgap and photocurrent enhancement are the most important parameters to describe novel photoactive materials. Table 4 shows a comparison of selected doped $\mathrm{TiO}_{2}$ materials obtained with different synthesis methods. Due to the various modifications of nanostructure, there are large discrepancies in photocurrent values. However, as the authors mentioned [64-66], introducing low amounts of chemical elements into the anatase structure promotes increasing the photoresponse. Too high doping level of $\mathrm{TiO}_{2}$ causes a decrease in photocurrent density. The photocurrent for $\mathrm{Co}-\mathrm{TiO}_{2}-\mathrm{NTs}$ obtained in this work is similar to the value in article [67]. The energies bandgap for doped titania nanotubes are in the range from $2.82 \mathrm{eV}$ to $3.09 \mathrm{eV}[64,68,69]$. Thin films of $\mathrm{TiO}_{2}$ with $\mathrm{Ag}$ or $\mathrm{Cu}$ dopant achieve lower Eg values, but they also have worse photoelectroactivity.

Table 4. Comparison of energy bandgap and photocurrent density for selected metal-doped $\mathrm{TiO}_{2}$ $\left(j_{\text {doped }}-\right.$ photocurrent density for doped $\mathrm{TiO}_{2}, j_{\mathrm{TiO} 2}$ - photocurrent density for pure $\left.\mathrm{TiO}_{2}\right)$.

\begin{tabular}{|c|c|c|c|c|c|}
\hline $\begin{array}{l}\text { Electrode } \\
\text { Material }\end{array}$ & $\begin{array}{c}\text { Luminous } \\
\text { Intensity } \\
\left(\mathrm{mW} \cdot \mathrm{cm}^{2}\right)\end{array}$ & $\begin{array}{c}\text { Energy } \\
\text { Bandgap, } \\
\mathrm{E}_{\mathrm{g}}(\mathrm{eV})\end{array}$ & $\begin{array}{c}\text { Photocurrent } \\
\text { Density } \\
\left(\mu \mathrm{A} \cdot \mathrm{cm}^{2}\right) / \mathrm{E}^{*}(\mathrm{~V})\end{array}$ & $\begin{array}{c}\text { Enhancement } \\
\text { Factor } \\
\left(j_{\text {doped }} / j_{\mathrm{TiO} 2}\right)\end{array}$ & Ref. \\
\hline $\mathrm{TiO}_{2}-\mathrm{NTs}$ & & 2.99 & 12.9 at $0.5 \mathrm{~V}$ & 1 & \\
\hline $\mathrm{Co}-\mathrm{TiO}_{2}$ & 100 & 2.85 & 12.0 at $0.5 \mathrm{~V}$ & 0.9 & This work \\
\hline $\mathrm{Co}-\mathrm{TiO}_{2}-\mathrm{NTs}$ & & 2.92 & 33.3 at $0.5 \mathrm{~V}$ & 2.6 & \\
\hline $\mathrm{Co}-\mathrm{TiO}_{2}-\mathrm{NTs}$ & 100 & 3.09 & 95.0 at $0.5 \mathrm{~V}$ & 1.5 & [68] \\
\hline $\mathrm{Co}-\mathrm{TiO}_{2}-\mathrm{NTs}$ & 100 & no data & 40.0 at $0.4 \mathrm{~V}$ & 3.0 & [67] \\
\hline $\mathrm{Cr}-\mathrm{TiO}_{2}-\mathrm{NTs}$ & 100 & 2.82 & 360.0 at $1.0 \mathrm{~V}$ & 9.2 & [64] \\
\hline $\mathrm{B}-\mathrm{TiO}_{2}-\mathrm{NTs}$ & 100 & 2.91 & 311.0 at $0.5 \mathrm{~V}$ & 7.4 & [69] \\
\hline $\mathrm{V}-\mathrm{TiO}_{2}-\mathrm{NTs}$ & 16 & no data & 5.8 at $0.5 \mathrm{~V}$ & 4.8 & [70] \\
\hline $\mathrm{Ag}-\mathrm{TiO}_{2}$ film & 4.4 & 2.5 & 1.2 at $0.2 \mathrm{~V}$ & 3.5 & [71] \\
\hline $\begin{array}{c}\mathrm{Fe}-\mathrm{TiO}_{2} \\
\text { nanorods }\end{array}$ & 100 & 3.12 & 550.0 at $0 \mathrm{~V}$ & 5.5 & {$[65]$} \\
\hline $\mathrm{Cu}-\mathrm{TiO}_{2}$ film & 44.42 & 2.82 & 18.2 at $0.4 \mathrm{~V}$ & 1.3 & [66] \\
\hline
\end{tabular}

As shown above, the cobalt doping of $\mathrm{TiO}_{2}$ nanotubes has an effect on both the reduction in the overpotential of water oxidation under dark conditions and the photooxidation process. This increase in photoactivity is the result of amplified absorption of visible light, a narrowing of the bandgap, and effective increase in the real surface area, all as a result of hydrothermal treatment in $\mathrm{CoCl}_{2}$ electrolyte.

\section{Conclusions}

A small amount of cobalt 0.1 at $\%$ has been successfully doped into $\mathrm{TiO}_{2}$ nanotubes using the hydrothermal method. Comprehensive characterization (XPS, XRD, EDX, Raman) confirms the introduction of $\mathrm{Co}^{2+}$ into the anatase crystal structure. Hydrothermal treatment of $\mathrm{TiO}_{2}-\mathrm{NTs}$ in $\mathrm{CoCl}_{2}$ electrolyte leads to an increase in the real surface area of the 
tubular structure. Titania is modified considering its morphology and electronic structure. Development of the real surface area and presence of Co-dopant are responsible for the significant rise in UV-Vis light absorption. Novel electrode material exhibits increased electroactivity towards water oxidation in the dark as an anodic threshold potential $\mathrm{E}_{\text {th }}$ is $100 \mathrm{mV}$ lower in comparison with $\mathrm{E}_{\mathrm{th}}$ for pure nanotubes. Moreover, the photoelectrocatalytic activity towards water oxidation is significantly enhanced, as a photocurrent of the modified sample $\mathrm{Co}-\mathrm{TiO}_{2}-\mathrm{NTs}$ is almost threefold higher in comparison to the photocurrent of pure nanotubes. The photoelectrocatalytic and electrocatalytic activity of cobalt-doped $\mathrm{TiO}_{2}$ nanotubes is attributed to their real surface increase and improved visible light absorption and, above all, their appropriate doped concentration. The presence of Co is necessary to reduce water oxidation potential in the dark and contributes to the growth of photocurrent.

Although we are aware that EDX elemental analysis of the samples combing both Ti support and the thin film only shows estimated values of Co-dopant, it is evident that hydrothermal low-temperature procedure leads to the formation of better photoanodic material. The further thermal treatment causes destruction of the tubular structure and leads to a hefty reduction in photocurrents while maintaining the catalytic properties for OER reactions in the dark. Our results are consistent with previously published data on photocatalytic activity of Co-doped titania [38,72].

Supplementary Materials: The following are available online at https:/ /www.mdpi.com/1996-194 4/14/6/1507/s1, Figure S1: EDX maps of the O, Ti and Co distributions.

Author Contributions: Conceptualization, A.L.-O.; resources, M.W., M.S. (Mirosław Sawczak), K.J., M.G., G.G.; data curation, M.W., M.G., M.S. (Mirosław Sawczak), M.S. (Mariusz Szkoda), K.J., G.G.; A.L-O.; writing—original draft preparation, A.L.-O., M.S.(Mariusz Szkoda), M.W.; writing—review and editing, A.L.-O., M.W., M.S.(Mariusz Szkoda); visualization, M.W., K.J., M.S. (Mirosław Sawczak); M.G., G.G., supervision, A.L.-O.; project administration, A.L.-O.; funding acquisition, M.S. (Mariusz Szkoda). All authors have read and agreed to the published version of the manuscript.

Funding: Authors A.L.-O. and M.W. are grateful for financial support from Gdańsk University of Technology Statutory financial support. M.S. (Mirosław Sawczak) and M.W. are grateful for financial support from The National Centre for Research and Development, grant no. LIDER/15/0088/L10/18/NCBR/2019 (Integrated prototype of a photo-supercapacitor for energy storage obtained as a result of solar radiation conversion).

Institutional Review Board Statement: Not applicable.

Informed Consent Statement: Not applicable.

Data Availability Statement: Data is contained within the article or supplementary material.

Conflicts of Interest: The authors declare no conflict of interest. The funders had no role in the design of the study; in the collection, analyses, or interpretation of data; in the writing of the manuscript, or in the decision to publish the results.

\section{References}

1. Chu, S.; Majumdar, A. Opportunities and challenges for sustainable energy future. Nature 2012, 488, 294-303. [CrossRef] [PubMed]

2. Pang, H.; Cao, X.; Zhu, L.; Zheng, M. Synthesis of Functional Nanomaterials for Electrochemical Energy Storage; Springer: Singapore, 2020.

3. Li-Oakey, K.D. Nanoporous Materials for Molecule Separation and Conversion; Elsevier: Amsterdam, The Netherlands, 2020; pp. 351-386.

4. Hi-Gang, C.; Guang, H.; Lei, Y.; Lina, C.; Jin, Z. Nanostructured thermoelectric materials: Current research and future challenge. Prog. Nat. Sci. Mater. Int. 2012, 22, 535-549.

5. Graetzel, M. Photoelectrochemical cells. Nature 2001, 44, 339-344. [CrossRef] [PubMed]

6. Opra, D.P.; Gnedenkov, S.V.; Sokolov, A.A.; Podgorbunsky, A.B.; Ustinov, A.Y.; Mayorov, V.Y.; Kuryavyi, V.G.; Sinebryukhov, S.L. Vanadium-doped $\mathrm{TiO}_{2}-\mathrm{B}$ /anatase mesoporous nanotubes with improved rate and cycle performance for rechargeable lithium and sodium batteries. J. Mater. Sci. Technol. 2020, 54, 181-189. [CrossRef] 
7. Opra, D.P.; Gnedenkov, S.V.; Sinebryukhov, S.L.; Podgorbunsky, A.B.; Sokolov, A.A.; Ustinov, A.Y.; Kuryavyi, V.G.; Mayorov, V.Y.; Zheleznov, V.V. Doping of titania with manganese for improving cycling and rate performances in lithium-ion batteries. Chem. Phys. 2020, 538, 110864. [CrossRef]

8. Fujishima, A.; Honda, K. Electrochemical Photolysis of Water at a Semiconductor Electrode. Nature 1972, 238, 37-38. [CrossRef] [PubMed]

9. Tan, H.L.; Amal, R.; Ng, Y.H. Alternative strategies in improving the photocatalytic and photoelectrochemical activities of visible light-driven $\mathrm{BiVO}_{4}$. J. Mater. Chem. A 2017, 5, 16498-16521. [CrossRef]

10. Cao, S.; Zhou, P.; Yu, J. Recent advances in visible light Bi-based photocatalysts. Chin. J. Catal. 2014, 35, $989-1007$.

11. Mehraj, O.; Pirzada, B.M.; Mir, N.A.; Khan, M.Z.; Sabir, S. A highly efficient visible-light-driven novel pn junction Fe $\mathrm{O}_{3} / \mathrm{BiOI}$ photocatalyst: Surface decoration of BiOI nanosheets with $\mathrm{Fe}_{2} \mathrm{O}_{3}$ nanoparticles. Appl. Surf. Sci. 2016, 387, 642-651. [CrossRef]

12. Li, D.; Shi, W. Recent developments in visible-light photocatalytic degradation of antibiotics. Chin. J. Catal. 2016, 37, 792-799. [CrossRef]

13. Lisowska-Oleksiak, A.; Szybowska, K.; Jasulajtiene, V. Preparation and characterisation of visible light responsive iodine doped TiO2 electrodes. Electrochim. Acta 2010, 55, 5881-5885. [CrossRef]

14. Bakar, S.A.; Ribeiro, C. Nitrogen-doped titanium dioxide: An over view of material design and dimensionality effect over modern applications. J. Photochem. Photobiol. C Photochem. Rev. 2016, 27, 1-29. [CrossRef]

15. Wysocka, I.; Kowalska, E.; Ryl, J.; Nowaczyk, G.; Zielinska, A. Morphology, Photocatalytic and Antimicrobial Properties of $\mathrm{TiO}_{2}$ Modified with Mono- and Bimetallic Copper, Platinum and Silver Nanoparticles. Nanomaterials 2019, 9, 1129. [CrossRef] [PubMed]

16. Macyk, W.; Szaciłowski, K.; Stochel, G.; Buchalska, M.; Kuncewicz, J.; Łabuz, P. Titanium (IV) complexes as direct TiO 2 photosensitizers. Coord. Chem. Rev. 2010, 254, 687-2701. [CrossRef]

17. Assefpour-Dezfuly, M.; Vlachos, C.; Andrews, E.H. Oxide morphology and adhesive bonding on titanium surfaces. J. Mater. Sci. 1984, 19, 3626-3639. [CrossRef]

18. Kasuga, T.; Hiramatsu, M.; Hoson, A.; Sekino, T.; Niihara, K. Formation of Titanium Oxide Nanotube. Langmuir 1998, 14, 3160-3163. [CrossRef]

19. Armstrong, A.R.; Canales, J.; García, R.; Bruce, P.G. Lithium-Ion Intercalation into $\mathrm{TiO}_{2}-\mathrm{B}$ Nanowires. Adv. Mater. 2005, 17, 862-865. [CrossRef]

20. Zwilling, V.; Aucouturier, M.; Darque-Ceretti, E. Anodic oxidation of titanium and TA6V alloy in chromic media. An electrochemical approach. Electrochim. Acta 1999, 45, 921-929. [CrossRef]

21. Macák, M.; Tsuchiya, H.; Schmuki, P. High-Aspect-Ratio $\mathrm{TiO}_{2}$ Nanotubes by Anodization of Titanium. Angew. Chem. Int. Ed. 2005, 44, 2100-2102. [CrossRef]

22. Albu, S.P.; Ghicov, A.; Macak, J.M.; Schmuki, P. $250 \mu \mathrm{m}$ long anodic $\mathrm{TiO}_{2}$ nanotubes with hexagonal self-ordering. Phys. Status Solidi Rapid Res. Lett. 2007, 1, 65-67. [CrossRef]

23. Fu, Y.; Mo, A. A review on the electrochemically self-organized titania nanotube arrays: Synthesis, modifications, and biomedical applications. Nanoscale Res. Lett. 2018, 13, 1-21. [CrossRef] [PubMed]

24. Yoo, J.E.; Schmuki, P. Critical factors in the anodic formation of extremely ordered titania nanocavities. J. Electrochem. Soc. 2019, 166, C3389-C3398. [CrossRef]

25. Qi, K.; Cheng, B.; Yu, J.; Ho, W. A review on $\mathrm{TiO}_{2}$-based Z-scheme photocatalysts. Chin. J. Catal. 2017, 38, 1936-1955. [CrossRef]

26. Jarosz, M.; Grudzien, J.; Kapusta-Kołodziej, J.; Chudecka, A.; Sołtys, M.; Sulka, G.D. Anodization of titanium alloys for biomedical applications. In Nanostructured Anodic Metal Oxides: Synthesis and Applications; Elsevier: Amsterdam, The Netherlands, 2020; p. 211.

27. Li, H.H.; Wu, X.Y.; Yin, S.; Katsumata, K.; Wang, Y.H. Effect of rutile $\mathrm{TiO}_{2}$ on the photocatalytic performance of g-C $\mathrm{N}_{3} / \mathrm{brookite}$ $\mathrm{TiO}_{2-\mathrm{x}} \mathrm{Ny}$ photocatalyst for NO decomposition. Appl. Surf. Sci. 2017, 392, 531-539. [CrossRef]

28. Szkoda, M.; Trzciński, K.; Nowak, A.P.; Coy, E.; Wicikowski, L.; Łapiński, M.; Siuzdak, K.; Lisowska-Oleksiak, A. Titania nanotubes modified by a pyrolyzed metal-organic framework with zero valent iron centers as a photoanode with enhanced photoelectrochemical, photocatalytical activity and high capacitance. Electrochim. Acta 2018, 278, 13-24. [CrossRef]

29. Paulose, M.; Mor, G.K.; Varghese, O.K.; Shankar, K.; Grimes, C.A. Visible light photoelectrochemical and water-photoelectrolysis properties of titania nanotube arrays. J. Photochem. Photobiol. A Chem. 2006, 178, 8-15. [CrossRef]

30. Schulte, K.L.; DeSario, P.A.; Gray, K.A. Effect of crystal phase composition on the reductive and oxidative abilities of TiO 2 nanotubes under UV and visible light. Appl. Catal. B Environ. 2010, 97, 354-360. [CrossRef]

31. Varghese, O.K.; Paulose, M.; Shankar, K.; Mor, G.K.; Grimes, C.A. Water-Photolysis Properties of Micron-Length Highly-Ordered Titania Nanotube-Arrays. J. Nanosci. Nanotechnol. 2005, 5, 1158-1165. [CrossRef]

32. Nah, Y.-C.; Paramasivam, I.; Schmuki, P. Doped $\mathrm{TiO}_{2}$ and $\mathrm{TiO}_{2}$ Nanotubes: Synthesis and Applications. ChemPhysChem 2010, 11, 2698-2713. [CrossRef]

33. Szkoda, M.; Siuzdak, K.; Lisowska-Oleksiak, A.; Karczewski, J.; Ryl, J. Facile preparation of extremely photoactive boron-doped $\mathrm{TiO}_{2}$ nanotubes arrays. Electrochem. Commun. 2016, 60, 212-215. [CrossRef]

34. Piątkowska, A.; Janus, M.; Szymański, K.; Mozia, S. C-, N- and S-Doped $\mathrm{TiO}_{2}$ Photocatalysts: A Review. Catalysts 2021, $11,144$. [CrossRef] 
35. Sekino, T.; Okamoto, T.; Kasuga, T.; Kusunose, T.; Nakayama, T.; Niihara, K. Synthesis and Properties of Titania Nanotube Doped with Small Amount of Cations. KEM 2006, 317-318, 251-254. [CrossRef]

36. Sołtys-Mróz, M.; Syrek, K.; Pierzchała, J.; Wiercigroch, E.; Malek, K.; Sulka, G.D. Band gap engineering of nanotubular $\mathrm{Fe}_{2} \mathrm{O}_{3}-\mathrm{TiO}_{2}$ photoanodes by wet impregnation. Appl. Surf. Sci. 2020, 517, 146195. [CrossRef]

37. Qarechalloo, S.; Naseri, N.; Salehi, F.; Moshfegh, A.Z. Simply tuned and sustainable cobalt oxide decorated titania nanotubes for photoelectrochemical water splitting. Appl. Surf. Sci. 2019, 464, 68-77. [CrossRef]

38. Jiang, P.; Xiang, W.; Kuang, J.; Liu, W.; Cao, W. Effect of cobalt doping on the electronic, optical and photocatalytic properties of $\mathrm{TiO}_{2}$. Solid State Sci. 2015, 46, 27-32. [CrossRef]

39. Monazzam, P.; Kisomi, B.F. Co/ $\mathrm{TiO}_{2}$ nanoparticles: Preparation, characterization and its application for photocatalytic degradation of methylene blue. Desalination Water Treat. 2017, 63, 283-292.

40. Preethi, T.; Abarna, B.; Vidhya, K.N.; Rajarajeswari, G.R. Sol-gel derived cobalt doped nano-titania photocatalytic system for solar light induced degradation of crystal violet. Ceram. Int. 2014, 40, 13159-13167. [CrossRef]

41. Wojdyr, M. Fityk: A general-purpose peak fitting program. J. Appl. Cryst. 2010, 43, 1126-1128. [CrossRef]

42. Available online: https://www.thermofisher.com/order/catalog/product/IQLAADGACKFAKRMAVI (accessed on 16 March 2021).

43. Szkoda, M.; Siuzdak, K.; Lisowka-Oleksiak, A. Optimization of electrochemical doping approach resulting in highly photoactive iodine-doped titania nanotubes. J. Sol. State Electrochem. 2016, 20, 563-569. [CrossRef]

44. Sulka, G.D.; Kapusta-Kołodziej, J.; Brzózka, A.; Jaskuła, M. Fabrication of nanoporous $\mathrm{TiO}_{2}$ by electrochemical anodization. Electrochim. Acta 2010, 55, 4359-4367. [CrossRef]

45. Zemann, J. Crystal structures. Acta Cryst. 1965, 18, 139. [CrossRef]

46. Spiridonova, J.; Katerski, A.; Danilson, M.; Krichevskaya, M.; Krunks, M.; Acik, I.O. Effect of the Titanium Isopropoxide: Acetylacetone Molar Ratio on the Photocatalytic Activity of $\mathrm{TiO}_{2}$ Thin Films. Molecules 2019, 24, 4326. [CrossRef]

47. Patterson, A.L. The scherrer formula for X-ray particle size determination. Phys. Rev. 1939, 56, 978-982. [CrossRef]

48. Chanda, A.; Rout, K.; Vasundhara, M.; Joshi, S.R.; Singh, J. Structural and magnetic study of undoped and cobalt doped TiO 2 nanoparticles. RSC Adv. 2018, 8, 10939-10947. [CrossRef]

49. Tian, F.; Zhang, Y.; Zhang, J.; Pan, C. Raman spectroscopy: A new approach to measure the percentage of anatase $\mathrm{TiO}_{2}$ exposed (001) facets. J. Phys. Chem. C 2012, 116, 7515-7519. [CrossRef]

50. Ohsaka, T.; Izumi, F.; Fujiki, Y. Raman spectrum of anatase, $\mathrm{TiO}_{2}$. J. Raman Spectrosc. 1978, 7, 321-324. [CrossRef]

51. Swamy, S.; Muddle, B.C.; Dai, Q. Size-dependent modifications of the Raman spectrum of rutile TiO 2 . Appl. Phys. Lett. 2006, 89, 163118. [CrossRef]

52. Bassi, A.L.; Cattaneo, D.; Russo, V.; Bottani, C.E.; Barborini, E.; Mazza, T.; Piseri, P.; Milani, P.; Ernst, F.O.; Wegner, K.; et al. Raman spectroscopy characterization of Titania nanoparticles produced by flame pyrolysis: The influence of size and stoichiometry. $J$. Appl. Phys. 2005, 98, 074305. [CrossRef]

53. Wint, T.H.M.; Smith, M.F.; Chanlek, N.; Chen, F.; Songsiriritthigul, P. Physical origin of diminishing photocatalytic efficiency for recycled $\mathrm{TiO}_{2}$ nanotubes and $\mathrm{Ag}$-loaded $\mathrm{TiO}_{2}$ nanotubes in organic aqueous solution. Catalysts 2020, 10, 737. [CrossRef]

54. Cabrera-German, D.; Gomez-Sosa, G.; Herrera-Gome, A. Accurate peak fitting and subsequent quantitative composition analysis of the spectrum of $\mathrm{Co} 2 \mathrm{p}$ obtained with $\mathrm{Al} \mathrm{K} \alpha$ radiation: I: Cobalt spinel. Surf. Interface Anal. 2016, 48, 252-256. [CrossRef]

55. Choudhury, B.; Choudhury, A.; Islam, A.M.; Alagarsamy, P.; Mukherjee, M. Effect of oxygen vacancy and dopant concentration on the magnetic properties of high spin $\mathrm{Co} 2 \mathrm{p}$ doped $\mathrm{TiO}_{2}$ nanoparticles. J. Magn. Magn. Mater. 2011, 323, 440-446. [CrossRef]

56. Lin, Y.B.; Yang, Y.M.; Zhuang, B.; Huang, S.L.; Wu, L.P.; Huang, Z.G.; Zhang, F.M.; Du, Y.W. Ferromagnetism of Co-doped TiO 2 films prepared by plasma enhanced chemical vapour deposition (PECVD) method. J. Phys. D Appl. Phys. 2008, $41,195007$. [CrossRef]

57. Li, J.G.; Buchel, R.; Isobe, M.; Mori, T.; Ishigaki, T. Cobalt-doped TiO2 nanocrystallites: Radio-frequency thermal plasma processing, phase structure, and magnetic properties. J. Phys. Chem. C 2009, 113, 8009-8015. [CrossRef]

58. Antonio, J.T.; Cortés-Jácome, M.; Orozco-Cerros, S.; Palacios, E.M.; Suárez-Parra, R.; Ángeles-Chávez, C.; Navarete, J.; LópezSalinas, E. Assessing optimal photoactivity on titania nanotubes using different annealing temperatures. Appl. Catal. B Environ. 2010, 100, 47-54. [CrossRef]

59. Mizukoshi, Y.; Ohtsu, N.; Masahashi, N. Structural and characteristic variation of anodic oxide on pure Ti with anodization duration. Appl. Surf. Sci. 2013, 283, 1018-1023. [CrossRef]

60. Dong, G.; Hu, H.; Huang, X.; Zhang, Y.; Bi, Y. Rapid activation of $\mathrm{Co}_{3} \mathrm{O}_{4}$ cocatalysts with oxygen vacancies on $\mathrm{TiO}_{2}$ photoanodes for efficient water splitting. J. Mater. Chem. A 2018, 6, 21003-21009. [CrossRef]

61. Szkoda, M.; Siuzdak, K.; Lisowska-Oleksiak, A. Non-metal doped $\mathrm{TiO}_{2}$ nanotube arrays for high efficiency photocatalytic decomposition of organic species in water. Phys. E Low-Dimens. Syst. Nanostruct. 2016, 84, 141-145. [CrossRef]

62. Bard, A.J.; Faulkner, L.R.; Wang, J. Electrochemical Methods: Fundamentals and Applications. J. Chem. Educ. 1983,60, A25.

63. Szkoda, M.; Trzciński, K.; Lisowska-Oleksiak, A.; Siuzdak, K. Electrochemical and photoelectrochemical properties of the interface between titania nanotubes covered by conducting polymer in aqueous-The effect of various geometry and electrolytes concentration. Appl. Surf. Sci. 2018, 448, 309-319. [CrossRef]

64. Momeni, M.M.; Ghayeb, Y. Photoelectrochemical water splitting on chromium-doped titanium dioxide nanotube photoanodes prepared by single-step anodizing. J. Alloys Compd. 2015, 637, 393-400. [CrossRef] 
65. Chakhari, W.; Naceur, J.B.; Taieb, S.B.; Assaker, I.B.; Chtourou, R. Fe-doped $\mathrm{TiO}_{2}$ nanorods with enhanced electrochemical properties as ef fi cient photoanode materials. J. Alloys Compd. 2017, 708, 862-870. [CrossRef]

66. Ganesh, I.; Kumar, P.P.; Annapoorna, I.; Sumliner, J.M.; Ramakrishna, M.; Hebalkar, N.Y.; Padmanabham, G. Applied Surface Science Preparation and characterization of $\mathrm{Cu}$-doped $\mathrm{TiO}_{2}$ materials for electrochemical, photoelectrochemical, and photocatalytic applications. Appl. Surf. Sci. 2014, 293, 229-247. [CrossRef]

67. Guaglianoni, W.C.; Florence, C.L.; Bonatto, F.; Venturini, J.; Arcaro, S.; Alves, A.K.; Bergmann, C.P. Novel nanoarchitectured cobalt-doped $\mathrm{TiO}_{2}$ and carbon nanotube arrays: Synthesis and photocurrent performance. Ceram. Int. 2019, 45, 2439-2445. [CrossRef]

68. Venturini, J.; Bonatto, F.; Guaglianoni, W.C.; Lemes, T.; Arcaro, S.; Alves, A.K.; Bergmann, C.P. Applied Surface Science Cobaltdoped titanium oxide nanotubes grown via one-step anodization for water splitting applications. Appl. Surf. Sci. 2019, 464, 351-359. [CrossRef]

69. Szkoda, M.; Lisowska-Oleksiak, A.; Siuzdak, K. Optimization of boron-doping process of titania nanotubes via electrochemical method toward enhanced photoactivity. J. Solid State Electrochem. 2016, 20, 1765-1774. [CrossRef]

70. Zhang, M.; Lu, D.; Zhang, Z.; Yang, J. Enhancement of visible-light-induced photocurrent and photocatalytic activity of V and N codoped $\mathrm{TiO}_{2}$ nanotube array films. J. Electrochem. Soc. 2014, 161, H416-H421. [CrossRef]

71. Gogoi, D.; Namdeo, A.; Kumar, A. ScienceDirect Ag-doped $\mathrm{TiO}_{2}$ photocatalysts with effective charge transfer for highly efficient hydrogen production through water splitting. Int. J. Hydrog. Energy 2019, 45, 2729-2744. [CrossRef]

72. Kongkanand, A.; Tvrdy, K.; Takechi, K.; Kuno, M.; Kamat, P.V. Quantum dot solar cells. Tuning photoresponse through size and shape control of CdSe- $-\mathrm{TiO}_{2}$ architecture. J. Am. Chem. Soc. 2008, 130, 4007-4015. [CrossRef] 